\title{
Synthetic Studies on Macrolactin A: Construction of C4-C24 Fragment
}

\author{
Marie Georgy $\stackrel{\ddagger}{\ddagger}$ Philippe Lesot ${ }^{\dagger}$ and Jean-Marc Campagne ${ }^{\ddagger}$,*
}

ICSN-CNRS Avenue de la Terrasse, 91198 Gif-sur-Yvette, France; ${ }^{\dagger}$ Laboratoire de Chimie Structurale Organique, RMN en Milieu Orienté, ICMMO, CNRS UMR 8182, Bât 410, Université Paris-Sud (XI), 91405 Orsay, France; ${ }^{\not}$ Ecole Nationale Supérieure de Chimie, 8 Rue de l'Ecole Normale, 34296 Montpellier, France.

jean-marc.campagne@enscm.fr

\section{SUPPORTING INFORMATION}

\section{CONTENTS}

- General experimental details

- Experimental procedures and characterization $(\mathbf{2}, \mathbf{6}, \mathbf{7}, \mathbf{9}, \mathbf{1 0}, \mathbf{1 4})$

$-{ }^{1} \mathrm{H}$ and ${ }^{13} \mathrm{C}$ NMR spectra 
General information : Unless otherwise stated all commercial materials were used without further purification. Reactions were carried out under argon atmosphere, in dry round bottom flasks equiped with a magnetic stirring bar and capped with a septum. Dichloromethane and triethylamine and dimethylformamide (reduced pressure) were distilled over $\mathrm{CaH}_{2}$. THF was distilled over sodium/benzophenone complex. Toluene was distilled over sodium. Isopropanol, methanol and ethanol were distilled over magnesium. 1,3-Diaminopropane was distilled over $\mathrm{BaO}$. Dimethylsulfoxyde was dried by distillation under reduced pressure. Dimethylformamide was distilled under reduced pressure over $\mathrm{CaH}_{2}$. For the two Noyori reductions, the solutions were degased three times by the Schlenk method : they were freezed under argon with liquid nitrogen, then warmed up to room temperature under vacuum. TLC analysis of all reactions was performed on silica gel $60 \mathrm{~F}_{254}$ TLC plates. Chromatography was carried out on silica gel $(40-63 \mu \mathrm{m})$ or 90 neutral aluminium oxide. ${ }^{1} \mathrm{H}$ and ${ }^{13} \mathrm{C}$ NMR spectra were recorded with 300 and $500 \mathrm{MHz}$ spectrometers and referenced to $\mathrm{CDCl}_{3}$ unless otherwise noted. 


\section{Non-3-yn-2-one (2)}

To a solution of 1-heptyne $\left(10 \mathrm{~mL}, 75 \mathrm{mmol}\right.$.) in THF $(50 \mathrm{~mL})$ at $0^{\circ} \mathrm{C}$ was added dropwise $n$ butyllithium (1.6 M in hexanes, $47 \mathrm{~mL}, 75 \mathrm{mmol}$.). The resulting mixture was stirred at $0^{\circ} \mathrm{C}$ for $1 \mathrm{~h}$, then added via cannula to a solution of acetic anhydride $(72 \mathrm{~mL}, 750 \mathrm{mmol})$ in THF $(75 \mathrm{~mL})$, at $-78^{\circ} \mathrm{C}$. The mixture was slowly warmed up to room temperature and stirred for 20h. It was then poured in a saturated solution of $\mathrm{NaHCO}_{3}$ and stirred for two days. The aqueous layer was extracted with $\mathrm{Et}_{2} \mathrm{O}$. The combined organic layers were washed with brine, dried on $\mathrm{MgSO}_{4}$, filtered and concentrated in vacuo. The crude product was distilled by means of a Kugelgohr $\left(90-105^{\circ} \mathrm{C}, 12\right.$ mbar) to afford the pure desired ketone $(6.15 \mathrm{~g}, 59 \%) . \mathrm{R}_{\mathrm{f}}=$ 0.60 (heptane/AcOEt 8:2). IR-FT (neat) $\mathrm{cm}^{-1} 3334,2934,2863,2209,1678(\mathrm{C}=\mathrm{O})$. NMR ${ }^{1} \mathrm{H}$ $\left(\mathrm{CDCl}_{3}, 300 \mathrm{MHz}\right) \mathrm{d} \mathrm{ppm}: 0.91(\mathrm{t}, J=6.9 \mathrm{~Hz}, 3 \mathrm{H}), 1.27-1.44(\mathrm{~m}, 4 \mathrm{H}), 1.54-1.63(\mathrm{~m}, 2 \mathrm{H})$, $2.33(\mathrm{~s}, 3 \mathrm{H}), 2.36(\mathrm{t}, J=7 \mathrm{~Hz}, 2 \mathrm{H}) . \mathrm{NMR}{ }^{13} \mathrm{C}\left(\mathrm{CDCl}_{3}, 75 \mathrm{MHz}\right) \delta \mathrm{ppm}: 13.9,19.0,22.2,27.5$, 31.1, 32.9, 81.5, 94.25, 185.0. Data in accordance with previously reported results. ${ }^{1}$

\section{(R)-Non-3-yn-2-ol (6) ${ }^{2}$}

A degased solution of complex $\left[\mathrm{RuCl}_{2}(p \text {-cymene })\right]_{2}(54 \mathrm{mg}, 0.086 \mathrm{mmol}$. $)$ and monotosyl diphenylethylenediamine ( $63 \mathrm{mg}, 0.17 \mathrm{mmol}$.) in isopropanol was warmed at $80^{\circ} \mathrm{C}$ for $1 \mathrm{~h}$, then cooled back to room temperature. Flame dried $\mathrm{KOH}$ ( $24 \mathrm{mg}, 0.43 \mathrm{mmol}$.) was added and the color solution changed from dark red to brown. A degased solution of ketone 2 (950 mg, 6.9 mmol.) in isopropanol was then added via cannula to the catalyst and the resultng mixture was stirred at room temperature for $40 \mathrm{~h}$. The solvent was evaporated and the crude product was purified by flash chromatography to afford the desired alcohol (774 mg, 78\%).

$[\alpha]_{\mathrm{D}}=+23.0\left(\mathrm{CHCl}_{3}, \mathrm{c}=1,25^{\circ} \mathrm{C}\right) ; \mathrm{ee}=95 \% . \mathrm{R}_{\mathrm{f}}=0.40$ (heptane/AcOEt 8:2). IR-FT (neat) $\mathrm{cm}^{-1}: 3338(\mathrm{OH}), 2933,2861(\mathrm{C} \equiv \mathrm{C}), 2732,2571,2440,2312,2248(\mathrm{C} \equiv \mathrm{C}) . \mathrm{NMR}{ }^{1} \mathrm{H}\left(\mathrm{CDCl}_{3}\right.$,

\footnotetext{
${ }^{1}$ Bellina, F.; Carpita, A.; Ciucci, D.; De Santis, M.; Rossi, R. Tetrahedron 1993, 49, 4677.

${ }^{2}$ Helal, C. J.; Magriotis, P. A.; Corey, E. J. J. Am. Chem. Soc. 1996, 118, 10938.
} 
$300 \mathrm{MHz}) \delta \mathrm{ppm}: 0.91(\mathrm{t}, J=6.9 \mathrm{~Hz}, 3 \mathrm{H}), 1.24-1.54(\mathrm{~m}, 6 \mathrm{H}), 1.44(\mathrm{~d}, J=6.5 \mathrm{~Hz}, 3 \mathrm{H}), 1.73$ $(\mathrm{d}, J=5.1 \mathrm{~Hz}, 1 \mathrm{H}), 2.20(\mathrm{td}, J=1.7 \mathrm{~Hz}, J=7 \mathrm{~Hz}, 2 \mathrm{H}), 4.47-4.57(\mathrm{~m}, 1 \mathrm{H}) . \mathrm{NMR}{ }^{13} \mathrm{C}\left(\mathrm{CDCl}_{3}\right.$, $75 \mathrm{MHz}) \delta \mathrm{ppm}: 14.1,18.8,22.3,24.9,28.5,31.2,58.8,82.3,84.9$. Data in accordance with previously reported results. $^{2}$

\section{((R)-non-8-yn-2-ol $(R)-7^{3}$}

A black suspension of lithium (298 mg g, $43 \mathrm{mmol}$ ) in dry 1,3-diaminopropane (29 $\mathrm{mL})$ was heated at $80^{\circ} \mathrm{C}$ until the metal was completely dissolved and the mixture turned white (around 1h30). It was then cooled down to room temperature and potassium tert-butoxide (3.2 g, 28.5 mmol.) was added. The mixture turned yellow at this point. After $30 \mathrm{~min}$. of stirring, the propagylic alcohol 6 (1.01 g, $7.2 \mathrm{mmol}$.) was added and the resulting mixture turned dark red. It was stirred for another $30 \mathrm{~min}$. then poured in ice-cold water. The aqueous layer was extracted with $\mathrm{Et}_{2} \mathrm{O}$. The combined organic layers were washed with $1 \mathrm{~N} \mathrm{HCl}$, then saturated $\mathrm{NaHCO}_{3}$, and finally with brine. The organic layer was then dried over $\mathrm{MgSO}_{4}$, filtered and concentrated in vacuo. The crude product was purified by flash chromatography to afford the desired product (736 mg, 73\%).

$[\alpha]_{\mathrm{D}}=-7.3\left(\mathrm{CHCl}_{3}, \mathrm{c}=1.02,25^{\circ} \mathrm{C}\right) ; \mathrm{ee}=96 \% . \mathrm{R}_{\mathrm{f}}=0.20$ (heptane/AcOEt 8:2). IR-FT (neat) $\mathrm{cm}^{-1}:$ 3922, $3357(\mathrm{OH}), 3308,2933,2860,2729,2671,2360,2117(\mathrm{C} \equiv \mathrm{C}) . \mathrm{NMR}{ }^{1} \mathrm{H}\left(\mathrm{CDCl}_{3}\right.$, $300 \mathrm{MHz}) \delta \mathrm{ppm}: 1.19(\mathrm{~d}, J=6.1 \mathrm{~Hz}, 3 \mathrm{H}), 1.32-1.59(\mathrm{~m}, 8 \mathrm{H}), 1.66(\mathrm{bs}, 1 \mathrm{H}), 1.95(\mathrm{t}, J=2.6$ $\mathrm{Hz}, 1 \mathrm{H}), 2.20(\mathrm{dd}, J=2.6 \mathrm{~Hz}, J=6.9 \mathrm{~Hz}, 2 \mathrm{H}), 3.75-3.85(\mathrm{~m}, 1 \mathrm{H}) . \mathrm{NMR}{ }^{13} \mathrm{C}\left(\mathrm{CDCl}_{3}, 75\right.$ MHz) $\delta$ ppm : 18.3, 23.5, 25.5, 28.4, 28.7, 39.1, 68.0, 68.2, 84.6. Data in accordance with previously reported results. $^{3}$

\footnotetext{
3 a) Schweitzer, S.; Vob, G.; Gerlach, H. Liebigs Ann Chem 1994, 189. b) Hamada, T.; Daikai, K.; Irie, R.; Katsuki, T. Tetrahedron: Asymmetry 1995, 6, 2441.
} 


\section{(R)-Ethyl 3-hydroxy-5-(4-methoxybenzyloxy)pentanoate (9) ${ }^{4}$}

A suspension of $\left[\mathrm{RuCl}_{2}\left(\mathrm{C}_{6} \mathrm{H}_{6}\right)\right]_{2}$ complex $(92 \mathrm{mg}, 0.18 \mathrm{mmol})$ and $(R)$-BINAP $(230 \mathrm{mg}, 0.36$ $\mathrm{mmol})$ in dry DMF $(6 \mathrm{~mL})$ was heated at $100^{\circ} \mathrm{C}$ for $10 \mathrm{~min}$., until complete dissolution, and then cooled down to room temperature. The dark red mixture was then added via cannula to a previously degased solution of $\beta$-keto ester $4(9.96 \mathrm{~g}, 35.5 \mathrm{mmol})$ in dry ethanol $(20 \mathrm{~mL})$. The resulting solution was placed under a 20 bar hydrogen atmosphere and stirred at room temperature for $62 \mathrm{~h}$. After evaporation of the solvents, the crude product was purified by flash chromatography to afford the desired alcohol 9 (8.62 g, 86\%).

$[\alpha]_{\mathrm{D}}=-14,5\left(\mathrm{CH}_{2} \mathrm{Cl}_{2}, \mathrm{c}=0.78,26^{\circ} \mathrm{C}\right) ;$ ee $98 \% . \mathrm{R}_{\mathrm{f}}=0.29$ (heptane/AcOEt 6:4). IR-FT (neat) $\mathrm{cm}^{-1}: 3491(\mathrm{OH}), 2936,2864,1732(\mathrm{C}=\mathrm{O}) . \mathrm{NMR}^{1} \mathrm{H}\left(\mathrm{CDCl}_{3}, 300 \mathrm{MHz}\right) \delta \mathrm{ppm}: 1.27(\mathrm{t}, J=$ $7.1 \mathrm{~Hz}, 3 \mathrm{H}), 1.76-1.81(\mathrm{~m}, 2 \mathrm{H}), 2.48(\mathrm{~d}, J=6.3 \mathrm{~Hz}, 2 \mathrm{H}), 3.40(\mathrm{~d}, J=3.3 \mathrm{~Hz}, 1 \mathrm{H}), 3.60-3.72$ $(\mathrm{m}, 2 \mathrm{H}), 3.81(\mathrm{~s}, 3 \mathrm{H}), 4.16(\mathrm{q}, J=7.2 \mathrm{~Hz}, 2 \mathrm{H}), 4.20-4.28(\mathrm{~m}, 1 \mathrm{H}), 4.45(\mathrm{~s}, 2 \mathrm{H}), 6.88(\mathrm{~d}, J=$ $8.7 \mathrm{~Hz}, 2 \mathrm{H}), 7.25(\mathrm{~d}, J=8.7 \mathrm{~Hz}, 2 \mathrm{H}) . \mathrm{NMR}{ }^{13} \mathrm{C}\left(\mathrm{CDCl}_{3} 75 \mathrm{MHz}\right) \delta \mathrm{ppm}: 14.2,36.0,41.6$, 55.3, 60.6, 67.1, 67.7, 73.0, 113.9, 129.3, 130.1, 159.3, 200.0. Chiral HPLC (Chiralpak ${ }^{\circledR}$ OD) Hexane/iPrOH 98:2; $1 \mathrm{~mL} / \min$. $\mathrm{t}_{\mathrm{R}}=10.2 \mathrm{~min}$. (maj.) $; \mathrm{t}_{\mathrm{R}}=13.2 \mathrm{~min}$. (min.) ; ee $=98 \%$. Data in accordance with previously reported results. ${ }^{4}$

\section{(R)-Ethyl 3-(tert-butyldimethylsilyloxy)-5-(4-methoxybenzyloxy)pentanoate (10) ${ }^{4}$}

To a solution of unprotected alcohol 9 (8.6 g, $30.5 \mathrm{mmol}$ ) ) and imidazole (3 g, 45.7 mmol.) in DMF (100 $\mathrm{mL})$ at room temperature was added TBDMSCl (7 g, $45.7 \mathrm{mmol}$.). The resulting mixture was stirred for $16 \mathrm{~h}$ and then treated with saturated $\mathrm{NH}_{4} \mathrm{Cl}(100 \mathrm{~mL})$. The aqueous layer was extracted with $\mathrm{Et}_{2} \mathrm{O}(500 \mathrm{~mL})$. The combined organic layers were washed with water and brine, dried over $\mathrm{MgSO}_{4}$, filtered and concentrated in vacuo. The crude product was purified by flash chromatography to afford the desired product $\mathbf{1 0}(11.3 \mathrm{~g}, 93 \%)$

\footnotetext{
${ }^{4}$ Herb, C.; Maier, M. E. J. Org. Chem. 2003, 68, 8129.
} 
$[\alpha]_{\mathrm{D}}=-10\left(\mathrm{CH}_{2} \mathrm{Cl}_{2}, \mathrm{c}=1.28,26^{\circ} \mathrm{C}\right) . \mathrm{R}_{\mathrm{f}}=0.76$ (heptane/AcOEt 6:4). IR-FT (neat) $\mathrm{cm}^{-1}: 2955$, 2931, 2899, 2857, $1736(\mathrm{C}=\mathrm{O}) . \mathrm{NMR}{ }^{1} \mathrm{H}\left(\mathrm{CDCl}_{3}, 500 \mathrm{MHz}\right) \delta \mathrm{ppm}: 0.05(\mathrm{~s}, 3 \mathrm{H}), 0.06$ (s, $3 \mathrm{H}), 0.86(\mathrm{~s}, 9 \mathrm{H}), 1.26(\mathrm{t}, J=7.1 \mathrm{~Hz}, 3 \mathrm{H}), 1.83(\mathrm{q}, J=6.3 \mathrm{~Hz}, 2 \mathrm{H}), 2.47(\mathrm{~d}, J=6.3 \mathrm{~Hz}, 2 \mathrm{H})$, $3.52(\mathrm{t}, J=6.4 \mathrm{~Hz}, 2 \mathrm{H}), 3.81(\mathrm{~s}, 3 \mathrm{H}), 4.0,6-4.17(\mathrm{~m}, 2 \mathrm{H}), 4.30$ (quint., $J=6.1 \mathrm{~Hz}, 1 \mathrm{H}), 4.40$ $(\mathrm{d}, J=11.2 \mathrm{~Hz}, 1 \mathrm{H}), 4.44(\mathrm{~d}, J=11.2 \mathrm{~Hz}, 1 \mathrm{H}), 6.88(\mathrm{~d}, J=8.5 \mathrm{~Hz}, 2 \mathrm{H}), 7.26(\mathrm{~d}, J=8.5 \mathrm{~Hz}$, 2H). NMR ${ }^{13} \mathrm{C}\left(\mathrm{CDCl}_{3}, 75 \mathrm{MHz}\right) \delta \mathrm{ppm}:-4.7,-4.5,14.4,18.1,25.9,37.5,43.2,55.4,60.4$, $66.4,67.1,72.7,113.9,129.4,130.7,159.3,171.8$.

Data in accordance with previously reported results. ${ }^{4}$

\section{$(S, 5 E, 7 E)-N o n a-1,5,7-t r i e n-4-o l ~(14)^{5}$}

Method A : To a solution of $(S)$-BINOL $(57 \mathrm{mg}, 0.2 \mathrm{mmol}$.) in dry dichloromethane $(2 \mathrm{~mL})$ were added crushed $4 \AA$ molecular sieves $(800 \mathrm{mg})$ and $\mathrm{Ti}(\mathrm{O} i \text {-Pr })_{4}(60 \mu \mathrm{L}, 0.2 \mathrm{mmol}$.). The red suspension was heated and stirred at reflux for $1 \mathrm{~h}$, then cooled down to room temperature. A solution of sorbaldehyde $(0.22 \mathrm{~mL}, 2 \mathrm{mmol}$.) in dry dichloromethane $(0.6 \mathrm{~mL})$ was then added, followed, after 5 minutes, by allyltributyltin $(0.75 \mathrm{~mL}, 2.4 \mathrm{mmol}$.). The flask was placed in a freezer $\left(-20^{\circ} \mathrm{C}\right)$ without stirring for 3 days. After being quenched with saturated $\mathrm{NaHCO}_{3}$ and stirred for $1 \mathrm{~h}$, the reaction mixture was filtered on a pad of celite. The filtrate was extracted with dichloromethane. The combined organic layers were dried over $\mathrm{MgSO}_{4}$, filtered and concentrated in vacuo. The crude product was purified by flash chromatography to afford $3 \mathrm{mg}$ of the desired product (1\%).

Method B : To a solution of $(S)$-BINOL (30 mg, $0.1 \mathrm{mmol}$.) in dry dichloromethane $(2 \mathrm{~mL})$ were added crushed $4 \AA$ molecular sieves $(400 \mathrm{mg})$ and $\mathrm{Ti}(\mathrm{O} i-\mathrm{Pr})_{4}(15 \mu \mathrm{L}, 0.05 \mathrm{mmol}$.). The red suspension was heated and stirred at reflux for $4 \mathrm{~h}$, then cooled down to $0^{\circ} \mathrm{C}$. A solution of

\footnotetext{
${ }^{5}$ Paquette, L. A.; Crouse, G. D.; Sharma, A. S. J. Am. Chem. Soc. 1982, 104, 4411.
} 
sorbaldehyde $(0.11 \mathrm{~mL}, 1 \mathrm{mmol})$ in dry dichloromethane $(0.5 \mathrm{~mL})$ was then added, followed, after 5 minutes, by allyltributyltin $\left(0.37 \mathrm{~mL}, 1.2 \mathrm{mmol}\right.$.) and $\mathrm{B}(\mathrm{OMe})_{3}(56 \mu \mathrm{L}, 0.5 \mathrm{mmol})$. The resulting mixture was slowly warmed up to room temperature and stirred for $20 \mathrm{~h}$. After being quenched with saturated $\mathrm{NaHCO}_{3}$ and stirred for $1 \mathrm{~h}$, the reaction mixture was filtered on a pad of celite. The filtrate was extracted with dichloromethane. The combined organic layers were dried over $\mathrm{MgSO}_{4}$, filtered and concentrated in vacuo. The crude product was purified by flash chromatography to afford $3 \mathrm{mg}$ of the desired product $(2 \%)$.

Method C : (S)-BINAP (96 mg, $0.15 \mathrm{mmol}$ ) and AgOTf (41 mg, $0.15 \mathrm{mmol}$.) were sheltered from light and stirred in dry THF $(1.5 \mathrm{~mL})$ for 15 minutes. A solution of sorbaldehyde $(55 \mu \mathrm{L}$, $0.5 \mathrm{mmol}$.) in dry THF $(0.5 \mathrm{~mL})$ was then added. The resulting mixture was cooled down to $-20^{\circ} \mathrm{C}$ and allyltributyltin $(0.16 \mathrm{~mL}, 0.51 \mathrm{mmol}$. $)$ was added. The solution was stirred at $-20^{\circ} \mathrm{C}$ for $20 \mathrm{~h}$, and then quenched with $1 \mathrm{~N} \mathrm{HCl}(2.5 \mathrm{~mL})$ and $\mathrm{KF}(0.5 \mathrm{mg})$. The slurry was stirred for another $4 \mathrm{~h}$ until a white precipitate was formed. The latter was filtered on a pad of silica and washed with $\mathrm{Et}_{2} \mathrm{O}(50 \mathrm{~mL})$. The filtrate was dried over $\mathrm{MgSO}_{4}$, filtered and concentrated in vacuo. The crude product was purified by flash chromatography to afford $50 \mathrm{mg}$ of the desired alcohol (72\%).

Method D : (S)-Tol-BINAP (34 mg, $0.05 \mathrm{mmol})$ and AgF (6 mg, $0.05 \mathrm{mmol}$.) were sheltered from light and stirred in dry methanol $(0.5 \mathrm{~mL})$ for 15 minutes. Sorbaldehyde $(28 \mu \mathrm{L}, 0.25$ mmol.) was then added. The resulting mixture was cooled down to $-20^{\circ} \mathrm{C}$ and allyltrimethoxysilane $\left(63 \mu \mathrm{L}, 0.51 \mathrm{mmol}\right.$.) was added. The solution was stirred at $-20^{\circ} \mathrm{C}$ for $3 \mathrm{~h}$, and then quenched with saturated $\mathrm{NH}_{4} \mathrm{Cl}$. The resulting mixture was filtered on a pad of celite and washed with $\mathrm{Et}_{2} \mathrm{O}$. The filtrate was dried over $\mathrm{MgSO}_{4}$, filtered and concentrated in vасио. The crude product was purified by flash chromatography to afford $15 \mathrm{mg}$ of the desired alcohol (43\%). 
Method E : $\mathrm{InCl}_{3}$ was placed in a round bottom flask under argon atmosphere and azeotropically dried with anhydrous THF three times prior to the addition of dry dichloromethane $(1.5 \mathrm{~mL})$. (S)-BINOL $(31 \mathrm{mg}, 0.11 \mathrm{mmol}$.$) , and crushed 4 \AA$ molecular sieves $(30 \mathrm{mg})$ were added and the mixture was stirred at room temperature for $2 \mathrm{~h}$. It was then cooled down to $-78^{\circ} \mathrm{C}$ and allyltributyltin $(0.31 \mathrm{~mL}, 1 \mathrm{mmol}$.) and sorbaldehyde $(55 \mu \mathrm{L}, 0.5$ mmol.) were added. The reaction mixture was slowly warmed up to room temperature and stirred for $16 \mathrm{~h}$. It was quenched with saturated $\mathrm{NaHCO}_{3}$. The aqeous layer was extracted with dichloromethane. The combined organic layers were washed with brine, dried over $\mathrm{MgSO}_{4}$, filtered and concentrated in vacuo. The crude product was purified by flash chromatography to afford $48 \mathrm{mg}$ of the desired alcohol (69\%).

$[\alpha]_{\mathrm{D}}=-10.4\left(\mathrm{CHCl}_{3}, \mathrm{c}=0.98,26^{\circ} \mathrm{C}\right) ;$ ee $=87 \%($ table 1 , entry 5$) . \mathrm{R}_{\mathrm{f}}=0,36($ heptane/AcOEt 8:2). NMR ${ }^{1} \mathrm{H}\left(\mathrm{C}_{6} \mathrm{D}_{6}, 300 \mathrm{MHz}\right) \delta \mathrm{ppm}: 1.57(\mathrm{~d}, J=6.8 \mathrm{~Hz}, 3 \mathrm{H}), 2.17(\mathrm{dd}, J=6.5 \mathrm{~Hz}, J=6.9$ $\mathrm{Hz}, 2 \mathrm{H}), 3.97(\mathrm{q}, J=6.4 \mathrm{~Hz}, 1 \mathrm{H}), 4.98(\mathrm{~d}, J=10.1 \mathrm{~Hz}, 1 \mathrm{H}), 4.99(\mathrm{~d}, J=16.2 \mathrm{~Hz}, 1 \mathrm{H}), 5.42-$ $5.56(\mathrm{~m}, 2 \mathrm{H}), 5.74(\mathrm{ddt}, J=7.1 \mathrm{~Hz}, J=9.6 \mathrm{~Hz}, J=16.8 \mathrm{~Hz}, 1 \mathrm{H}), 5.95(\mathrm{dd}, J=10.1 \mathrm{~Hz}, J=$ $15.2 \mathrm{~Hz}, 1 \mathrm{H}), 6.13(\mathrm{dd}, J=10.1 \mathrm{~Hz}, J=15.2 \mathrm{~Hz}, 1 \mathrm{H}) . \mathrm{NMR}{ }^{13} \mathrm{C}\left(\mathrm{C}_{6} \mathrm{D}_{6}, 75 \mathrm{MHz}\right) \delta \mathrm{ppm}$ : 18.1, 42.5, 71.6, 117.6, 129.1, 130.7, 131.7, 133.5, 134.9. MS (EI) m/z 121 (5), 97 (16), 81 (50), 71 (34), 69 (100), 41 (51). Data in accordance with previously reported results. ${ }^{5}$ Chiral HPLC (Chiralpak ${ }^{\circledR}$ OD) Hexane/iPrOH 99.5:0.5; $1 \mathrm{~mL} / \mathrm{min} . ; \mathrm{t}_{\mathrm{R}}=17.7$ min. $(R) ; \mathrm{t}_{\mathrm{R}}=$ $27.1 \min .(S)$ 


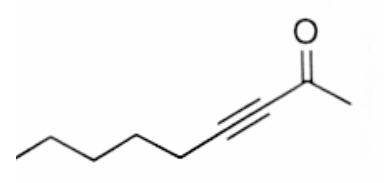

-S9-

2.57 3.00 
-S10-

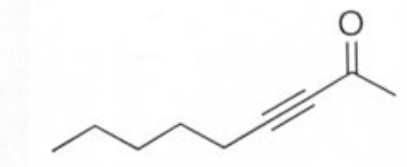

$2(13 \mathrm{C}$ NMR)

$\stackrel{\alpha}{\stackrel{\alpha}{g}}$

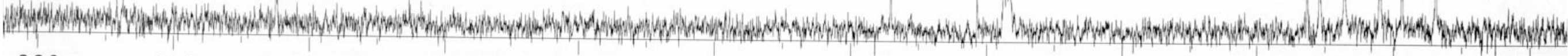

200

180

160

140

120

100

60

40

20 
$\frac{\bar{E}}{\frac{2}{2}} \quad \cdots$

$\mathrm{OH}$
Y

$6(1 \mathrm{H}$ NMR $)$

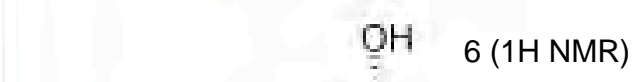

5

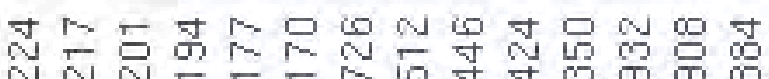

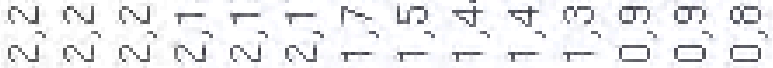

$-S 11$
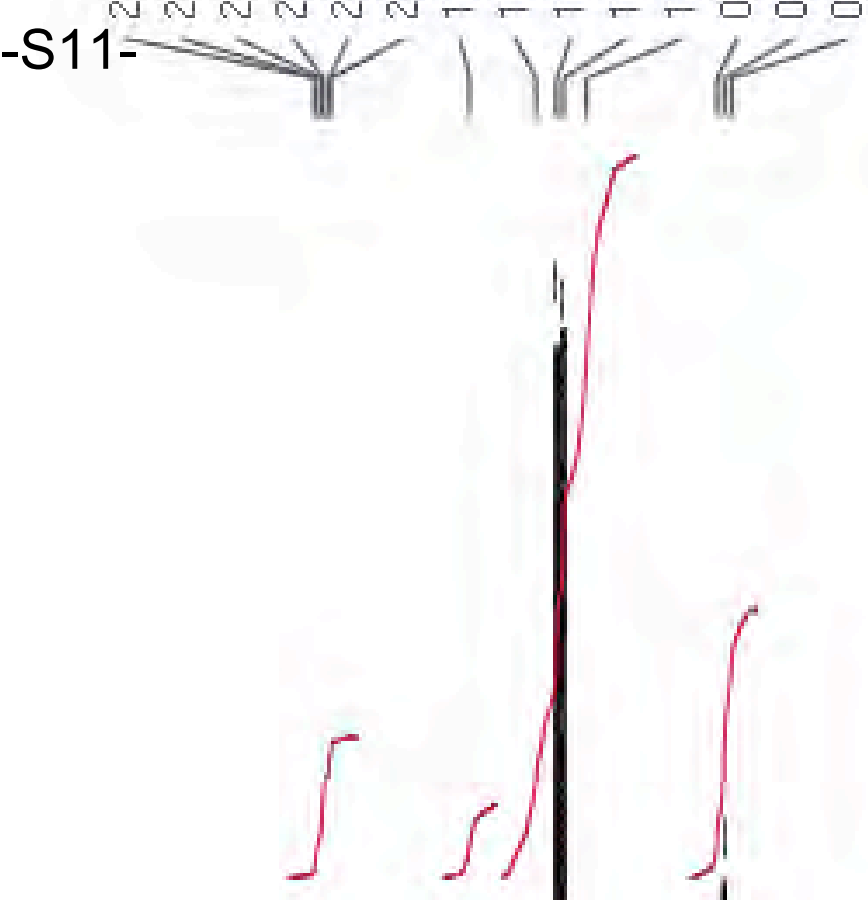

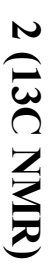

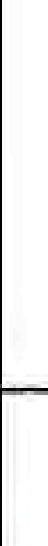

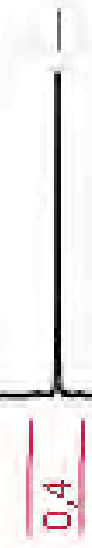
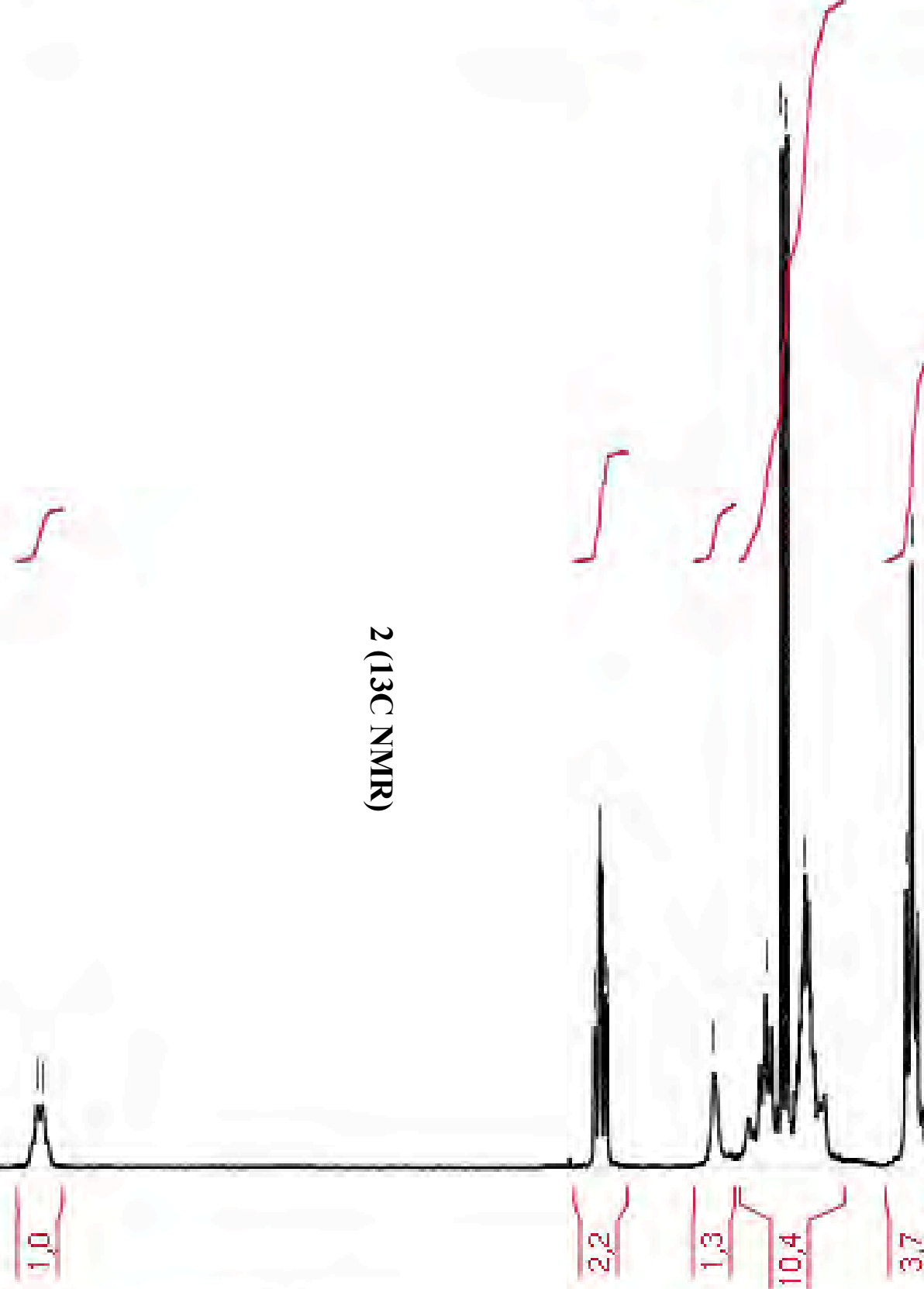


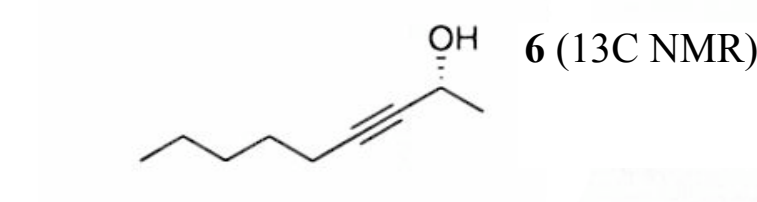

-S12-

31.18

28.49

24.91

18.754 .11

58.75

22.33

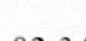

82.34

$7 7 \longdiv { 3 7 }$

Whathow 
7 (13C NMR)

-S14-

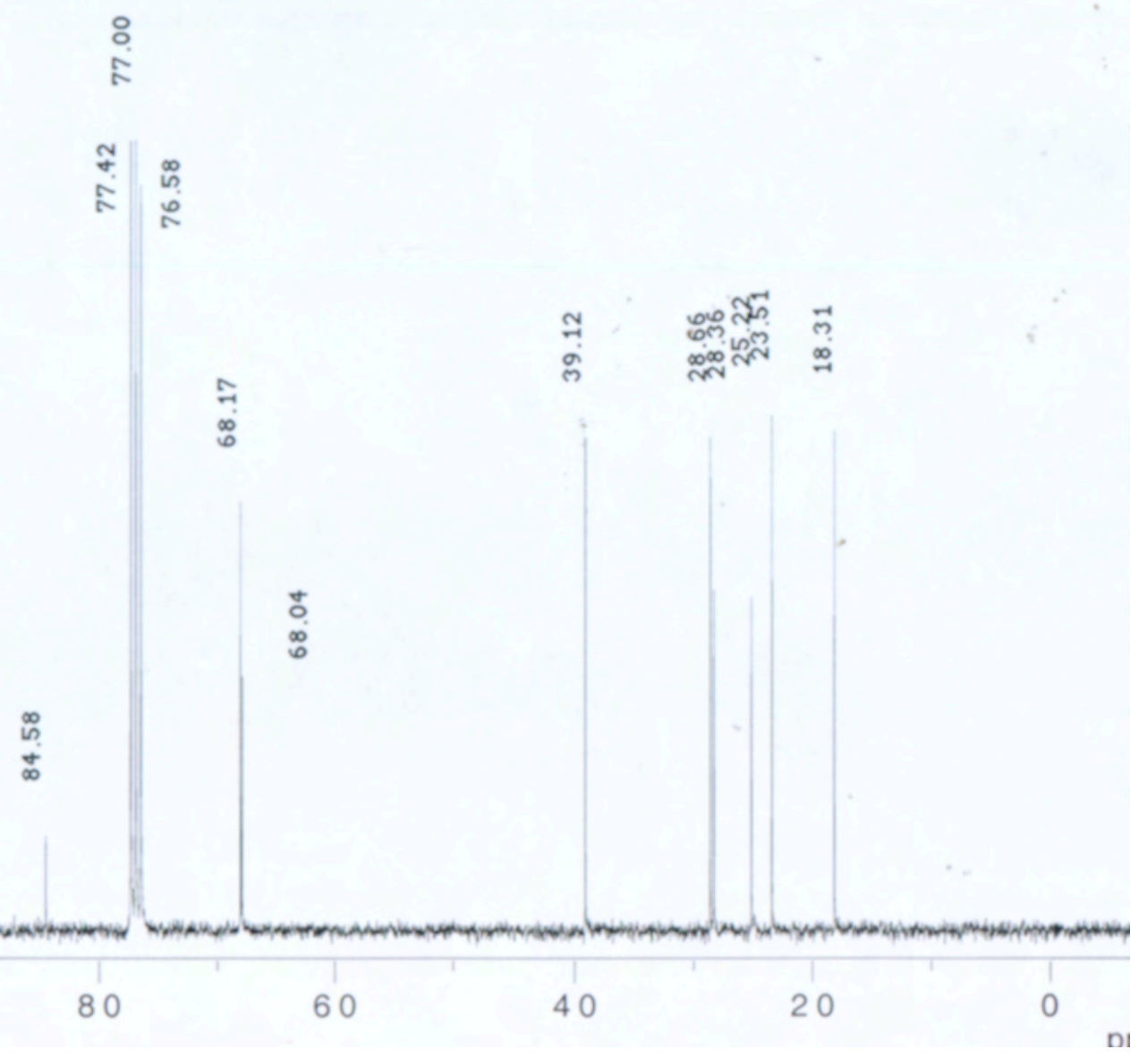




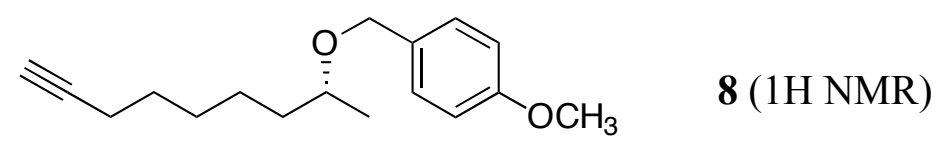

-S15-

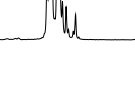

6.0

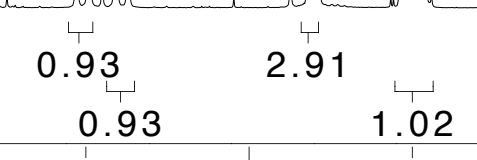

4.0

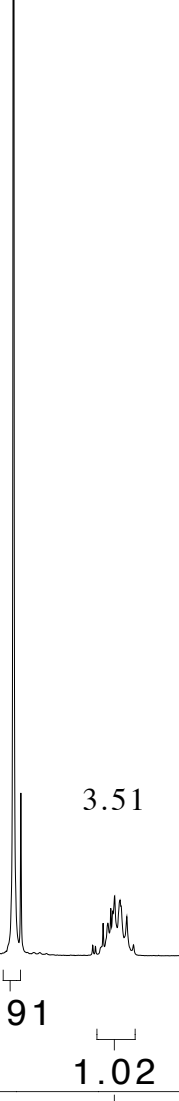

3.0

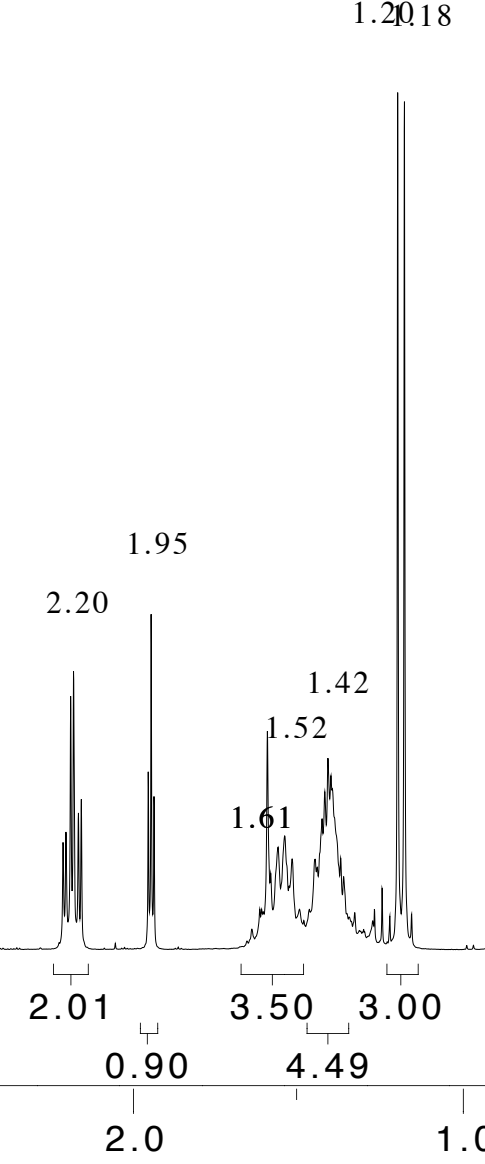




\section{MAD462_c13.swan}

$5 / 10 / 06$

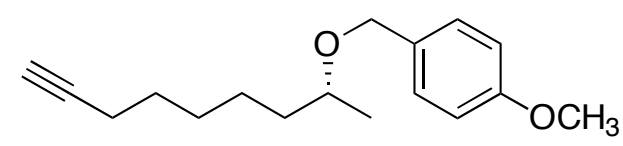

-S16-

$\mathrm{OCH}_{3}$

\section{8 (13C NMR)}

129.32

113.89

159.18

131.39

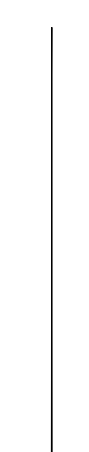

129.87
84.85

$$
\begin{aligned}
& 74.5510 \\
& 55.43 \\
& 36.70282985 .63 \quad 18.52
\end{aligned}
$$

19.80

68.27

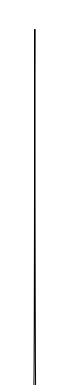

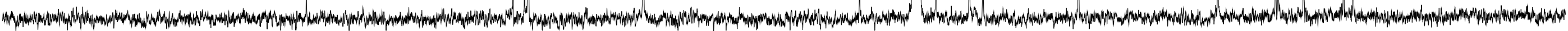




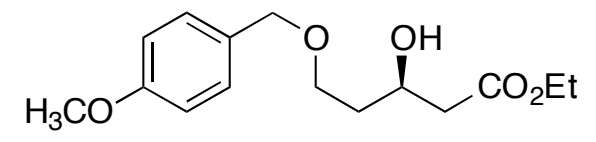

-S17-

9 (1H NMR)

3.82

$7.25 \quad 6.90$

4.46

2.51

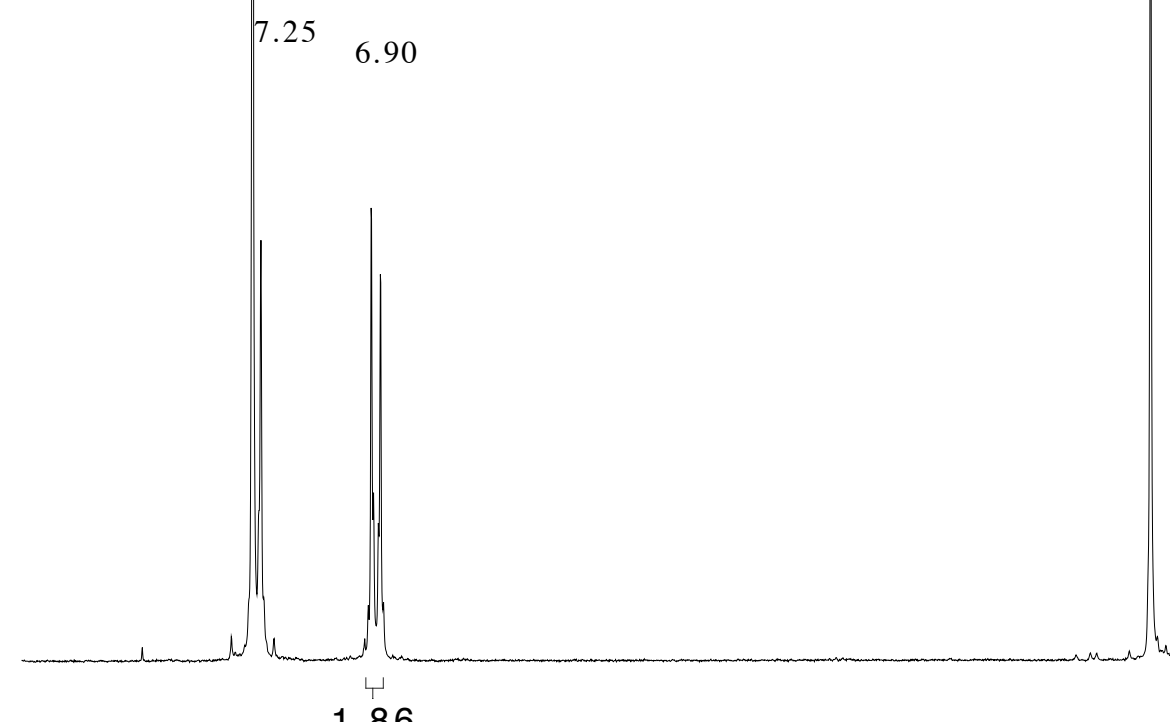

4.19

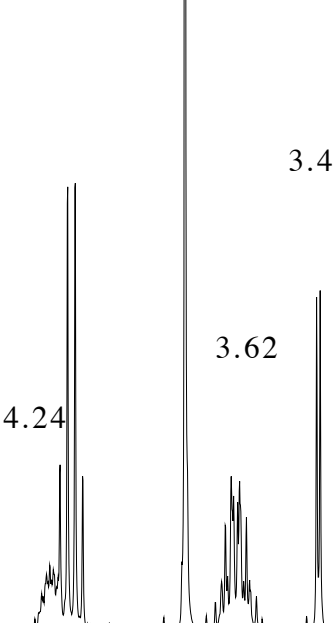

.56

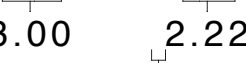

$2.97 \quad 0.90$

1.88

3.58 


\section{MAD310F2C13.swan}

住

67.08

$\begin{array}{rrr}67.08 & 55.30 & \\ 67.72 & & 41.6236 .04\end{array}$

60.62

14.22

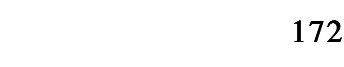




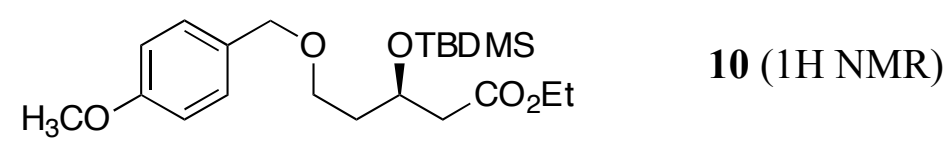

-S19-

0.061

0.046

7.27

6.87

4.42

3.52

2.46

1.84

$1.60 \quad 1.26$

0.86

3.81

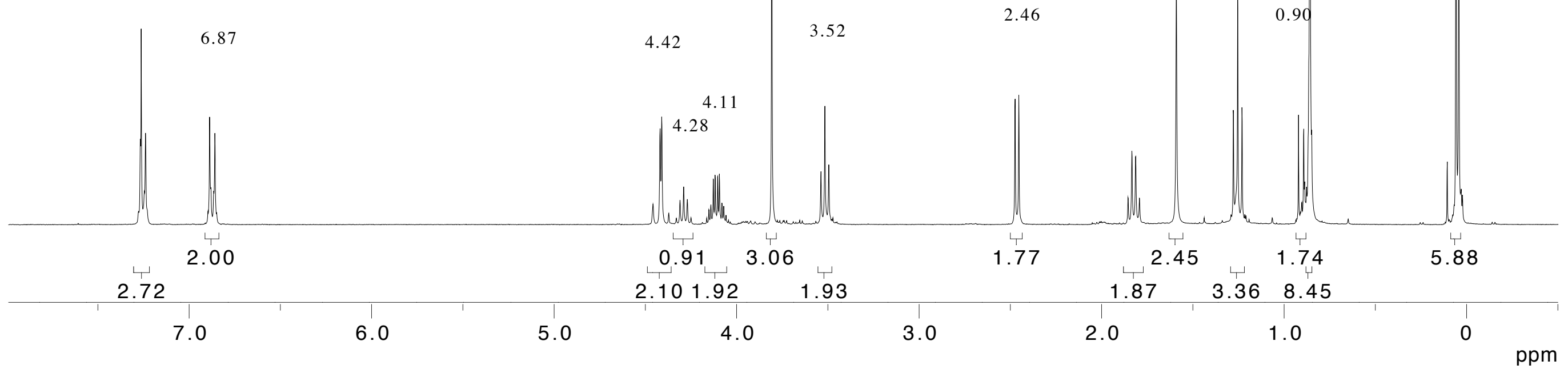




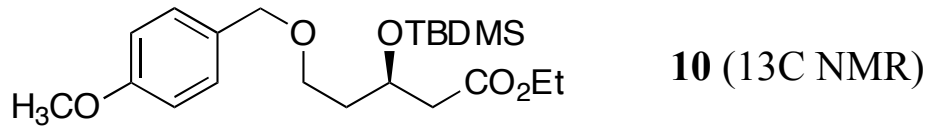

171.77

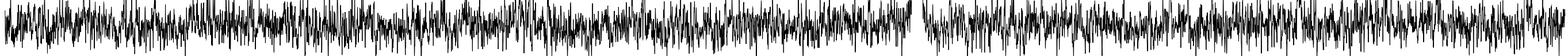

$72.74 \quad 43.16$

77.36

$67.14^{60.46}$

55.44

130.70

76.97
37.53
14.35

18.13 


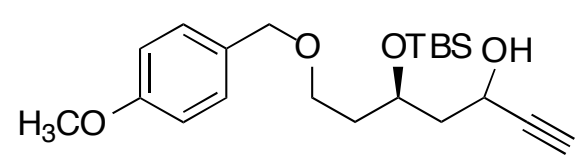

$-S 21-$

3 (1H NMR)

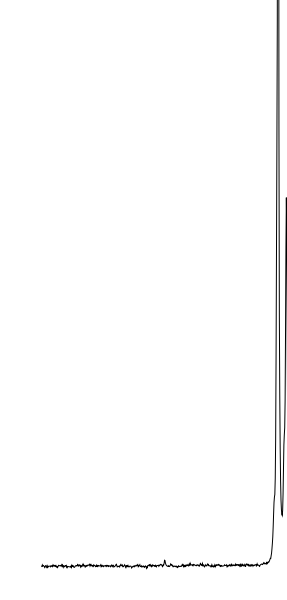

$$
4.44
$$

8.62

$$
4.92
$$

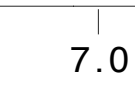
$1.06 .13 \quad 1.84$ 7.86

4.0 1.46

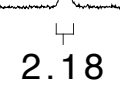
5.0

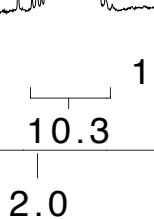
4.84 
-S22-

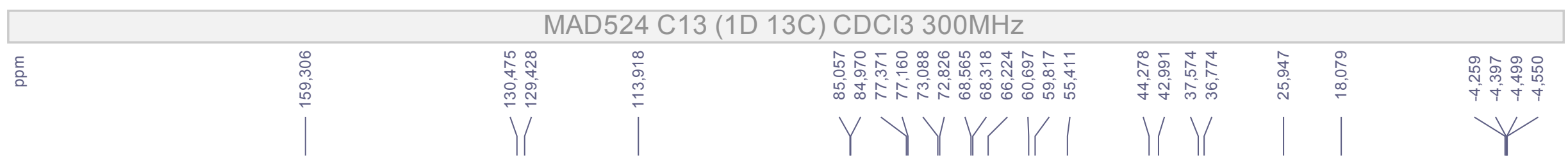

$$
\mathrm{H}_{3} \mathrm{CO}
$$

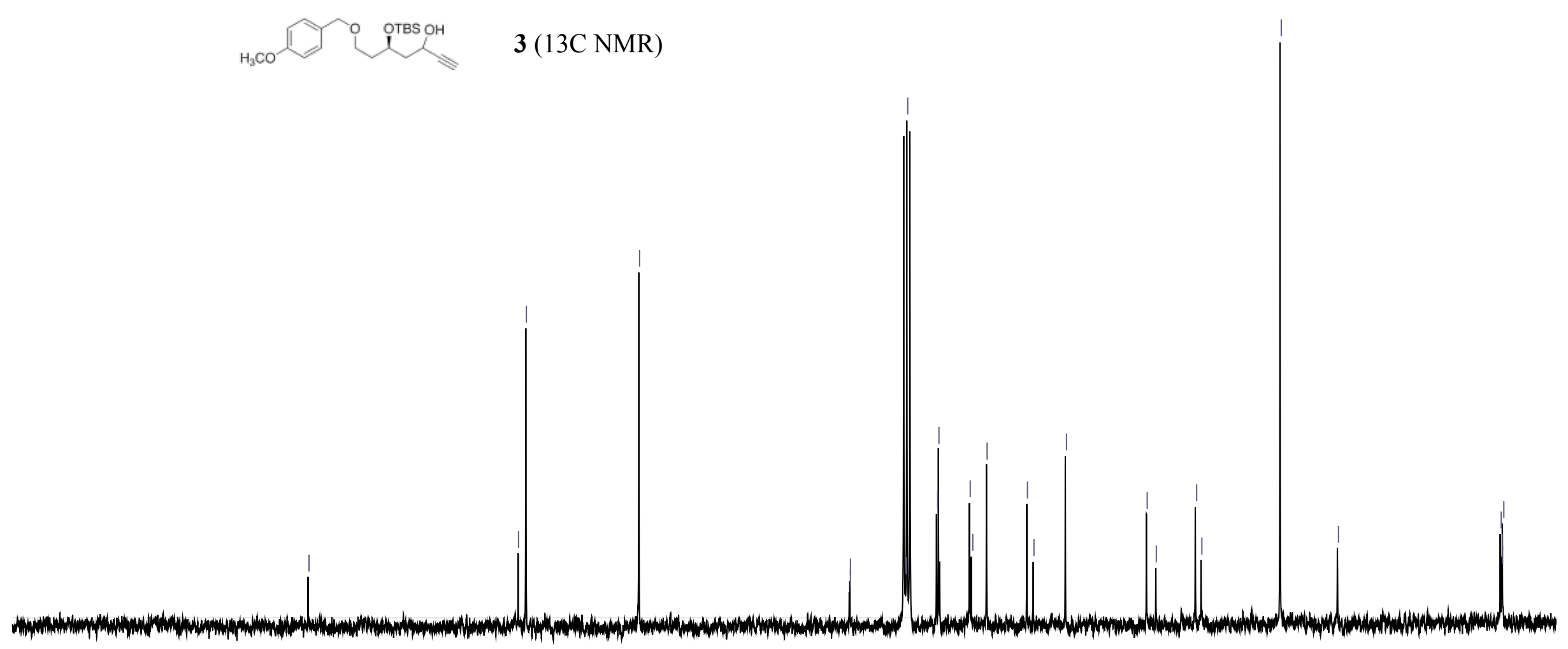



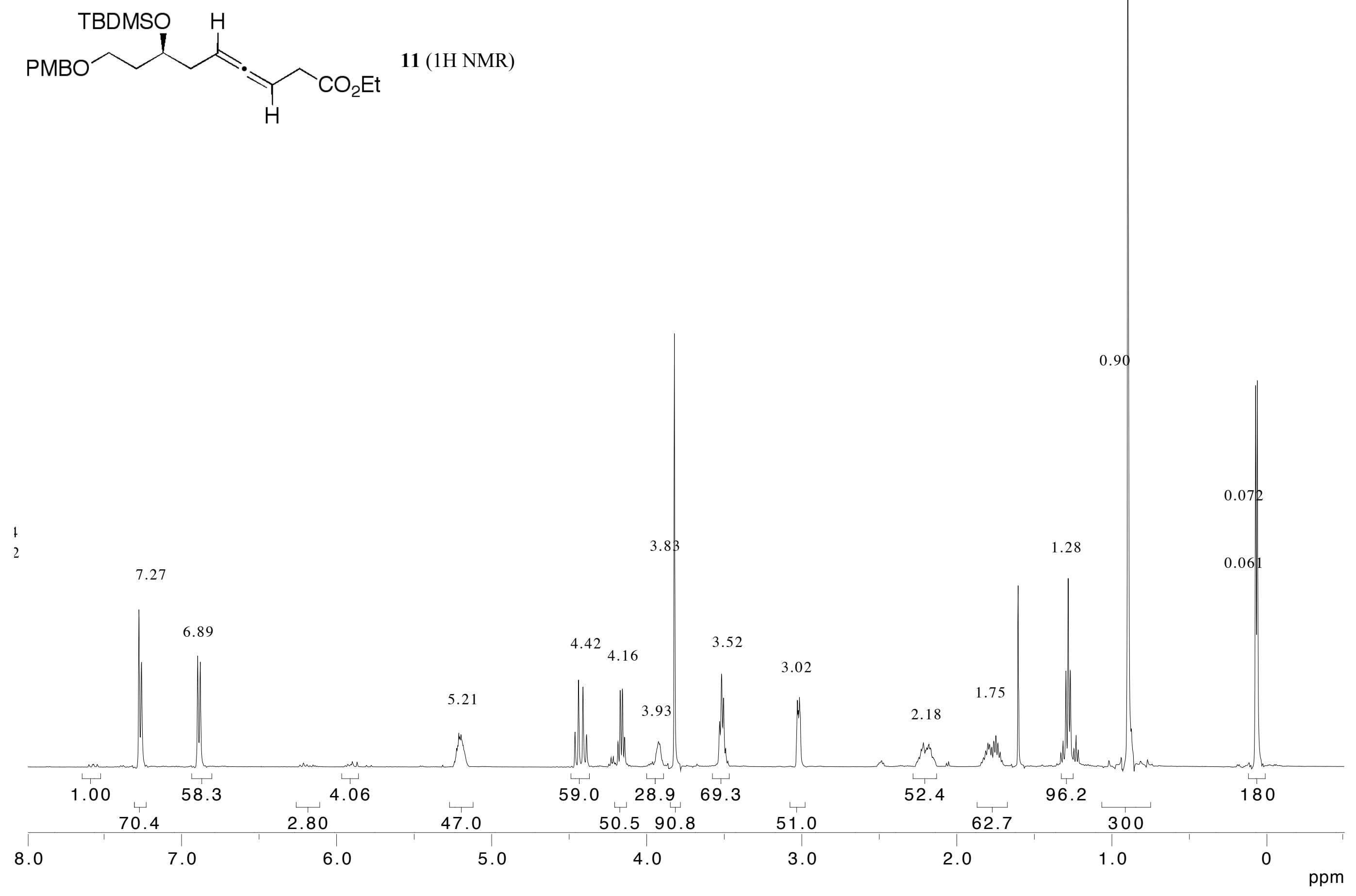
TBDMSO

-S24-

113.89

129.40

206.06

$171.71 \quad 159.26$

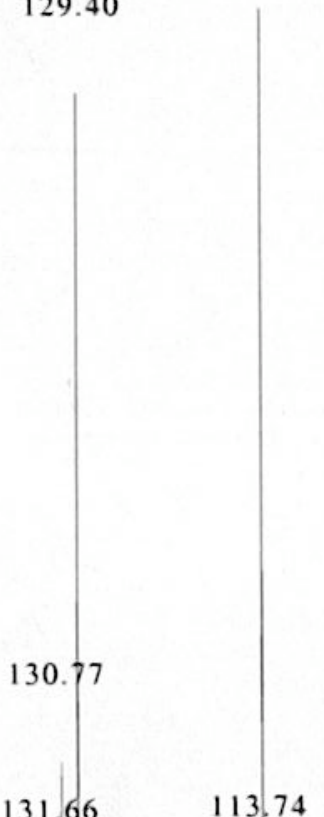

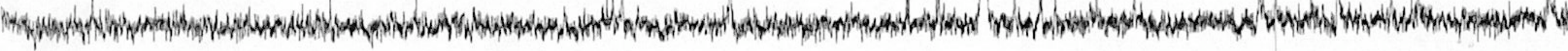

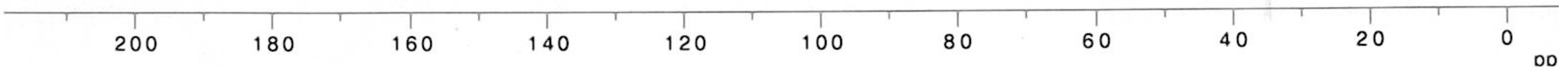


-S25-

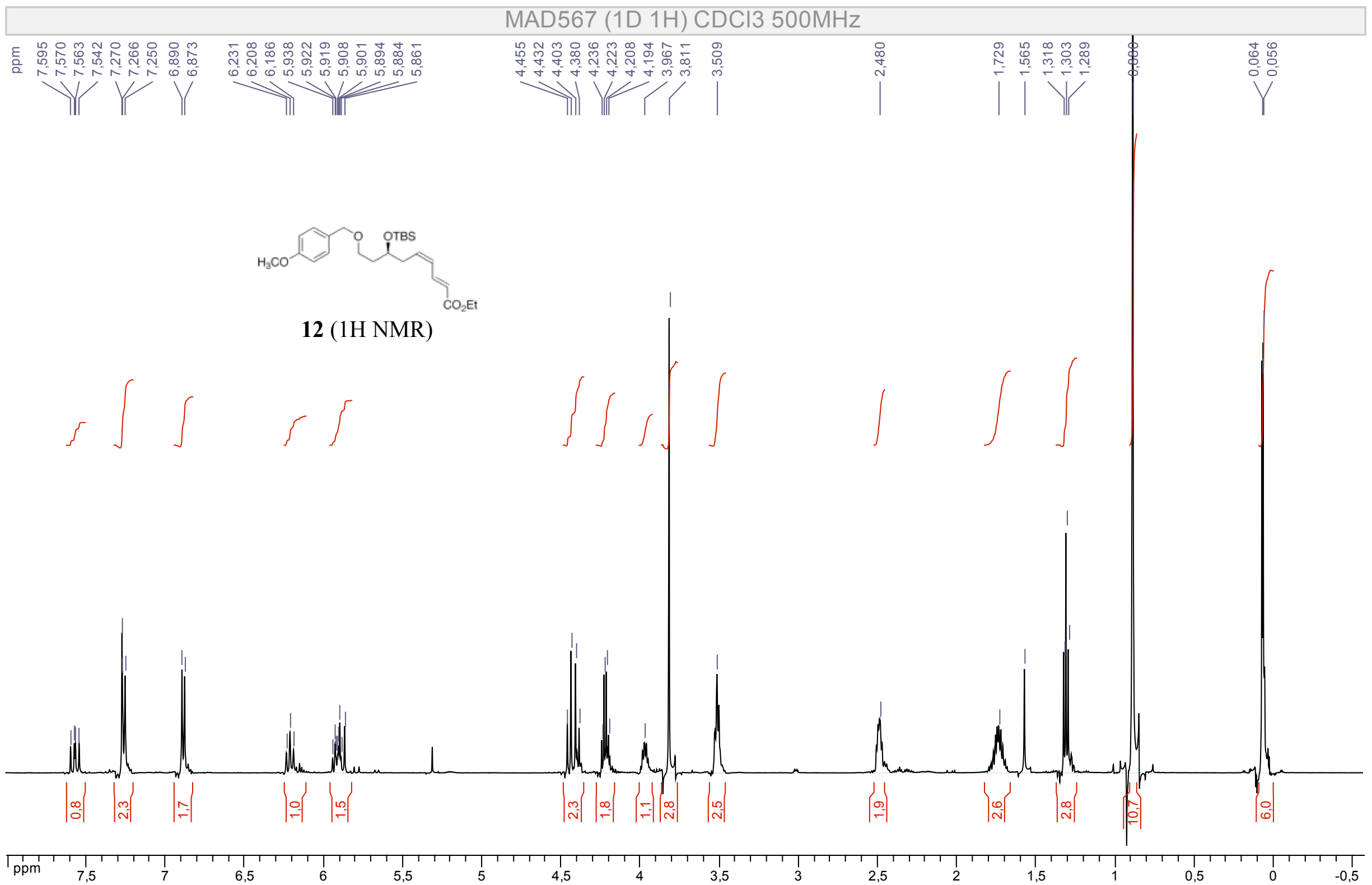


-S26-

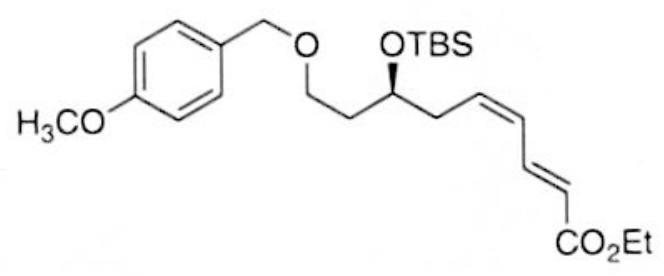

12 (13C NMR)

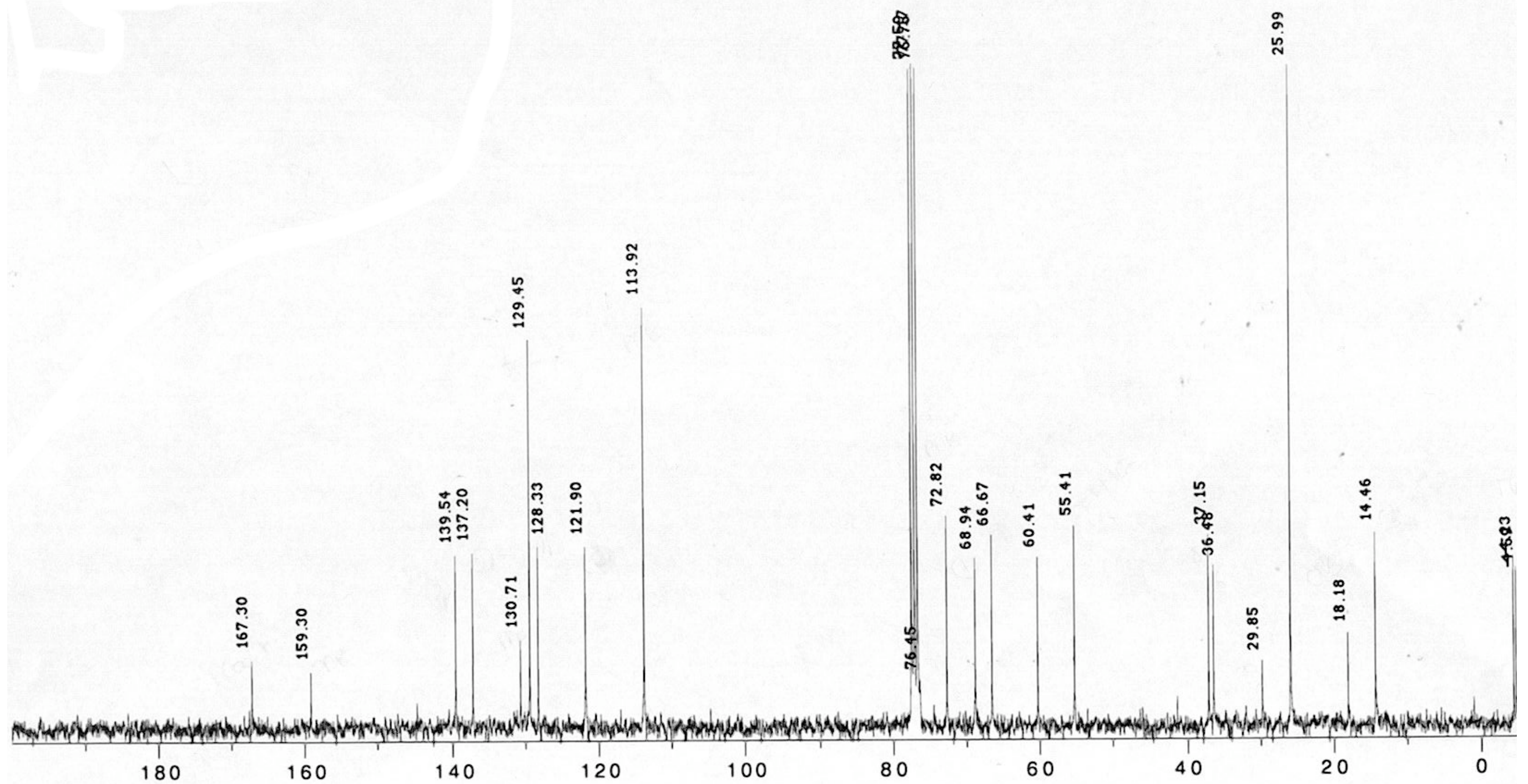




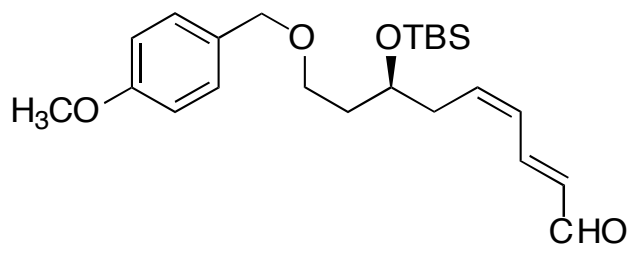

13 (1H NMR)

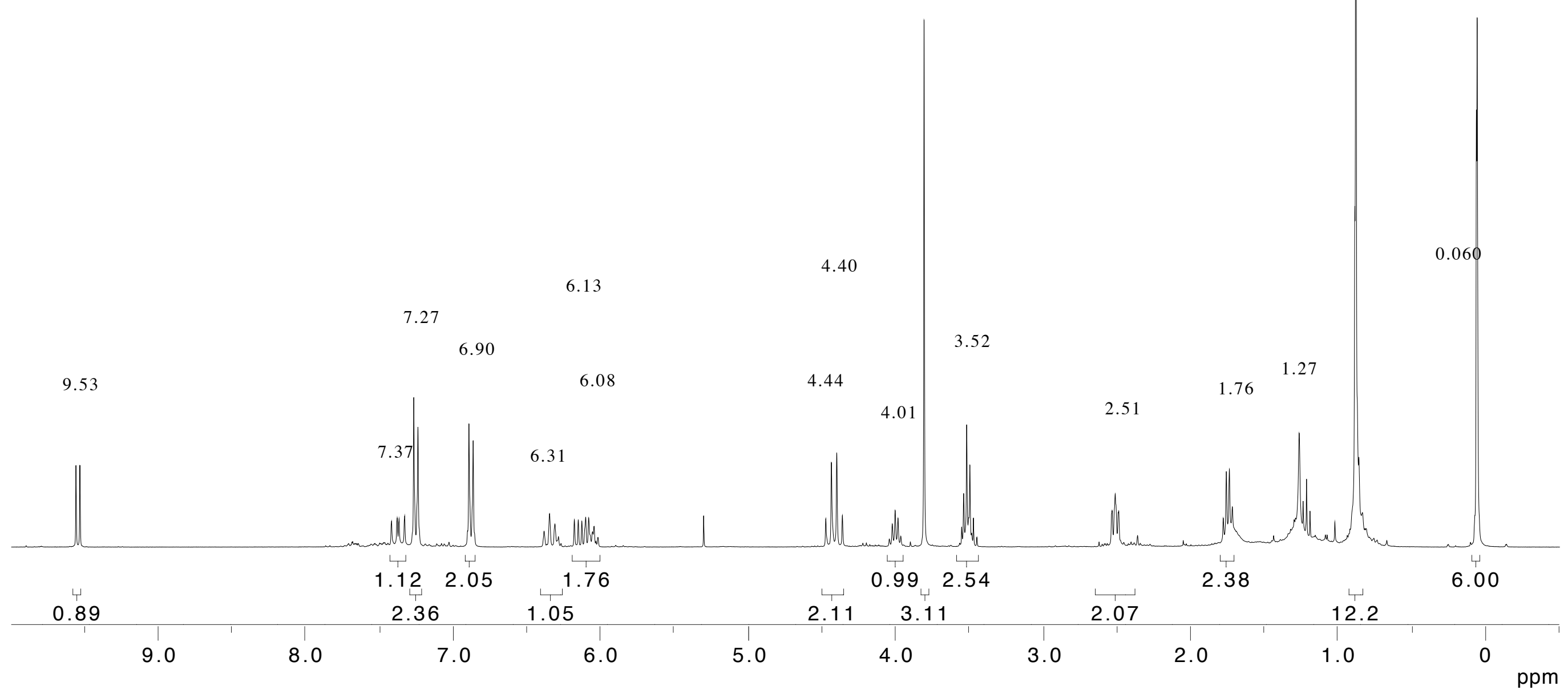


MAD433_c13.swan

$5 / 10 / 0 \overline{6}$

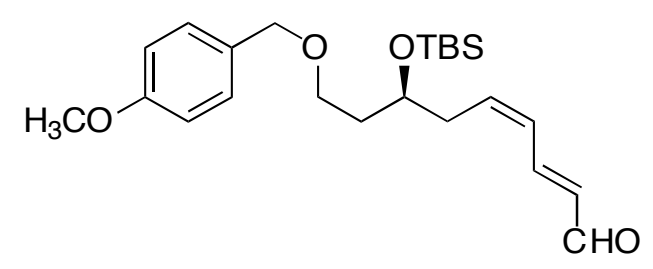

13 (13C NMR)

-S28-

$129.42 \quad 113.91$

194.11

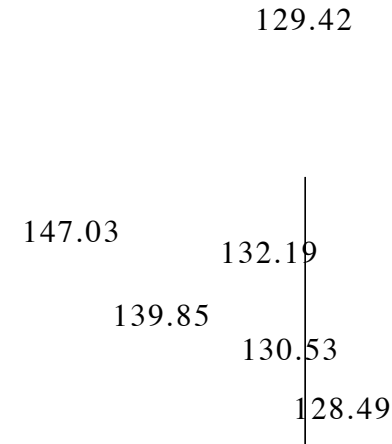

159.31

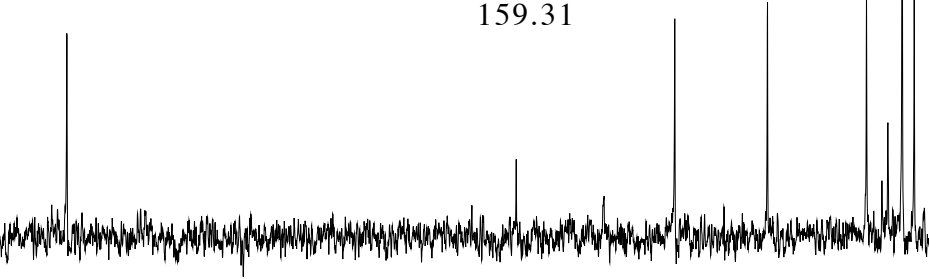

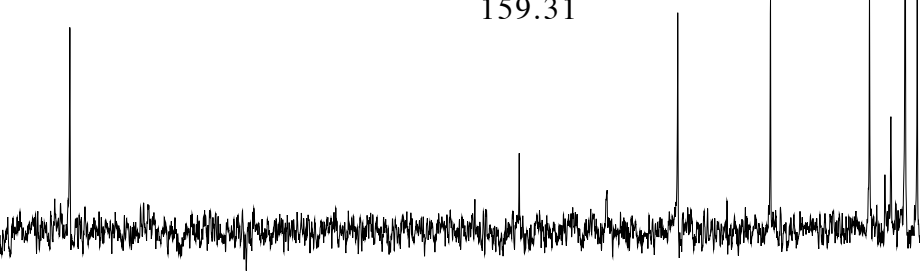

68.87

72.84
25.94

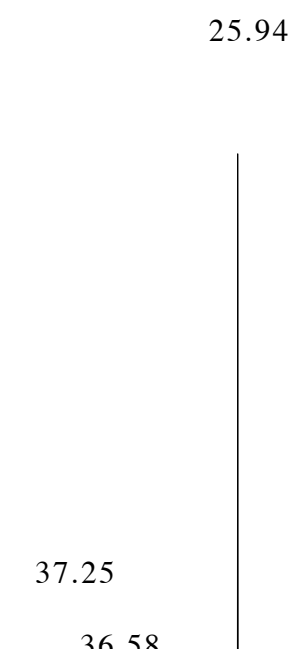

$-4.69$

$-4.37$

18.13 
-S29-

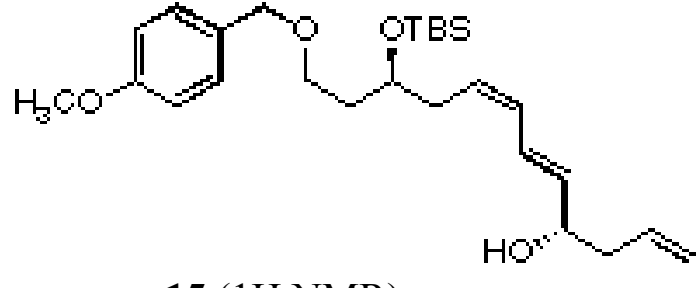

15 (1H NMR)

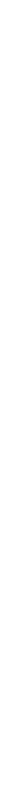




\section{MAD447ZE_c13.swan}

$5 / 10 / 06$

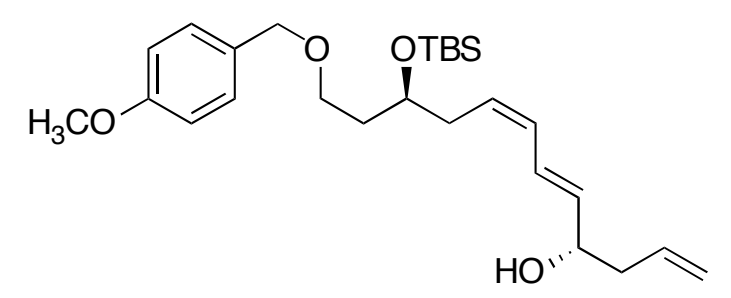

-S30-

15 (13C NMR)

130.79

129.54

129.41

113.91

159.26

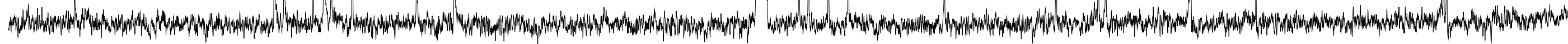

\begin{tabular}{|c|c|c|c|c|c|c|c|c|c|c|c|c|c|c|c|c|c|}
\hline & 1 & 1 & | & 1 & 1 & 1 & 1 & 1 & T & 1 & 1 & 1 & 1 & 1 & 1 & 1 & $T$ \\
\hline 160 & 150 & 140 & 130 & 120 & 110 & 100 & 90 & 80 & 70 & 60 & 50 & 40 & 30 & 20 & 10 & 0 & -10 \\
\hline
\end{tabular}


-S31-

MAD596 (1D 1H) CDCl3 300MHz

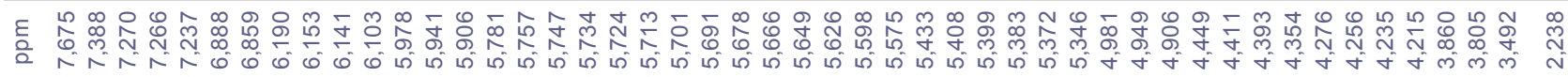

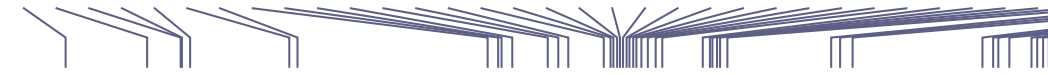

noo 092

$16(1 \mathrm{H}$ NMR $)$

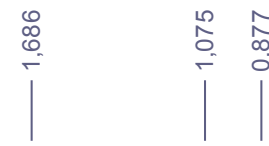

(4)
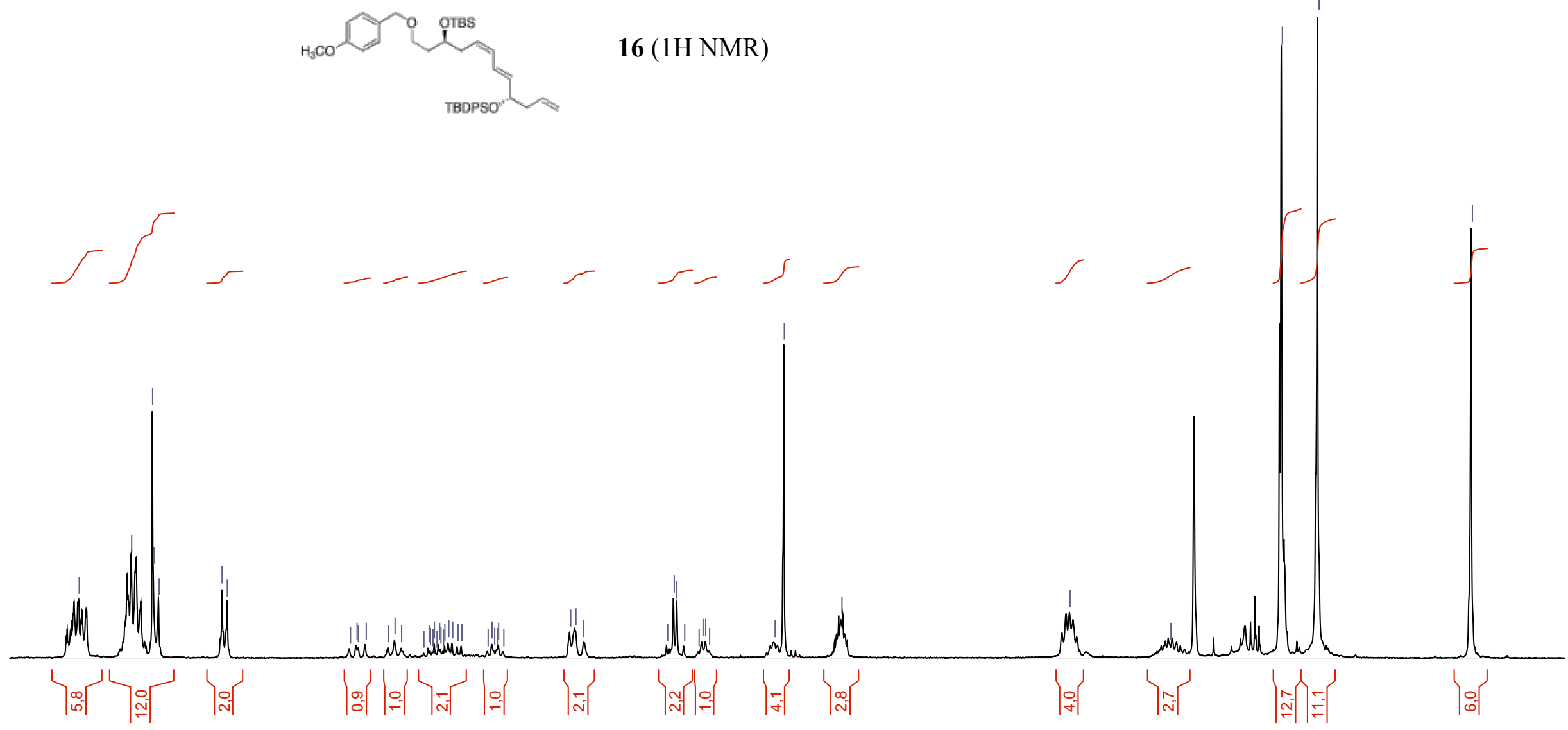
-S32-
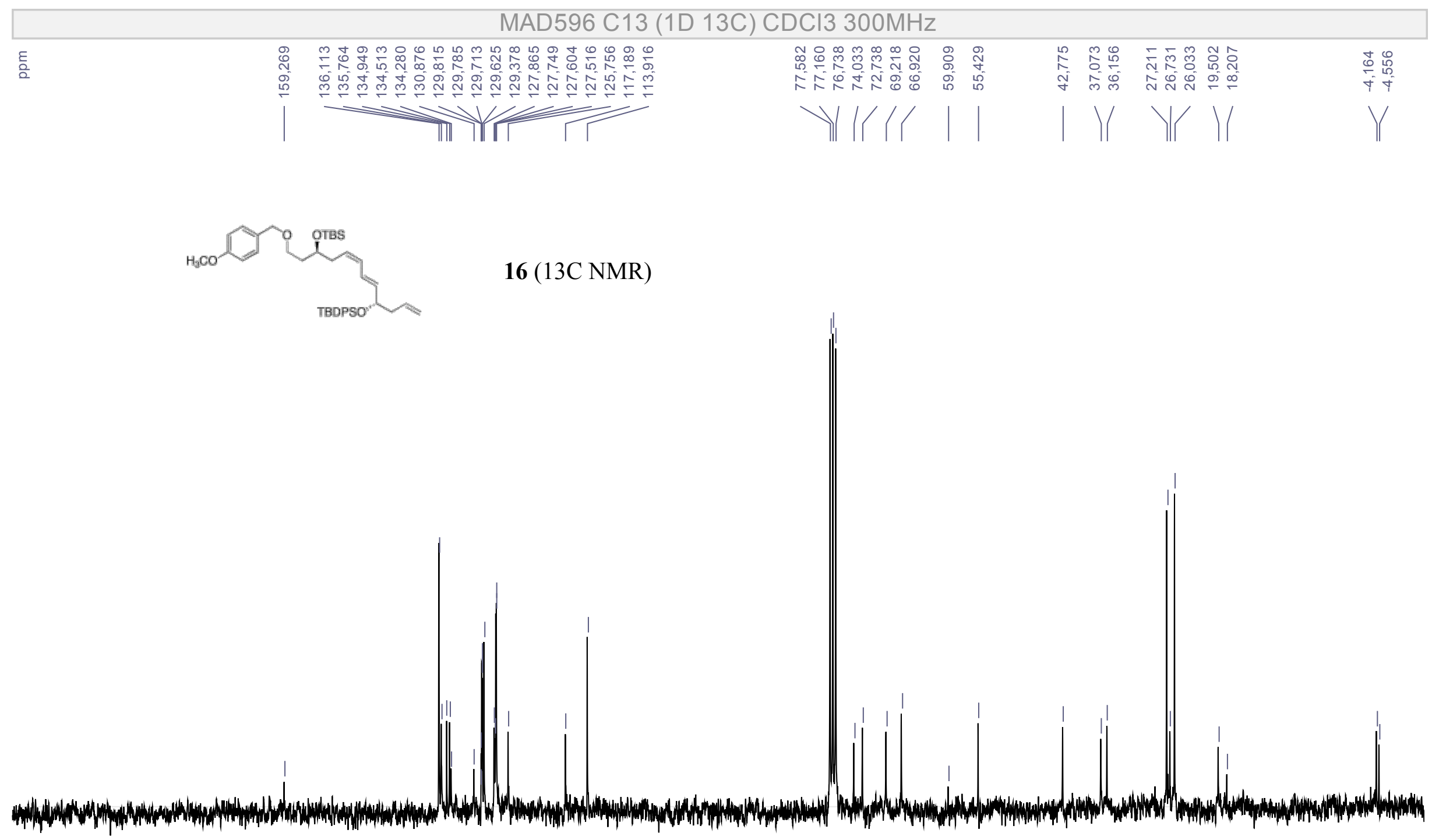
-S33-

MAD620 1H (1D 1H) CDCl3 300MHz

드으.

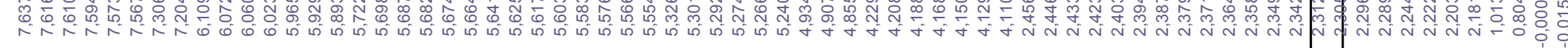
IIII |ाIा| \|\|$\|$
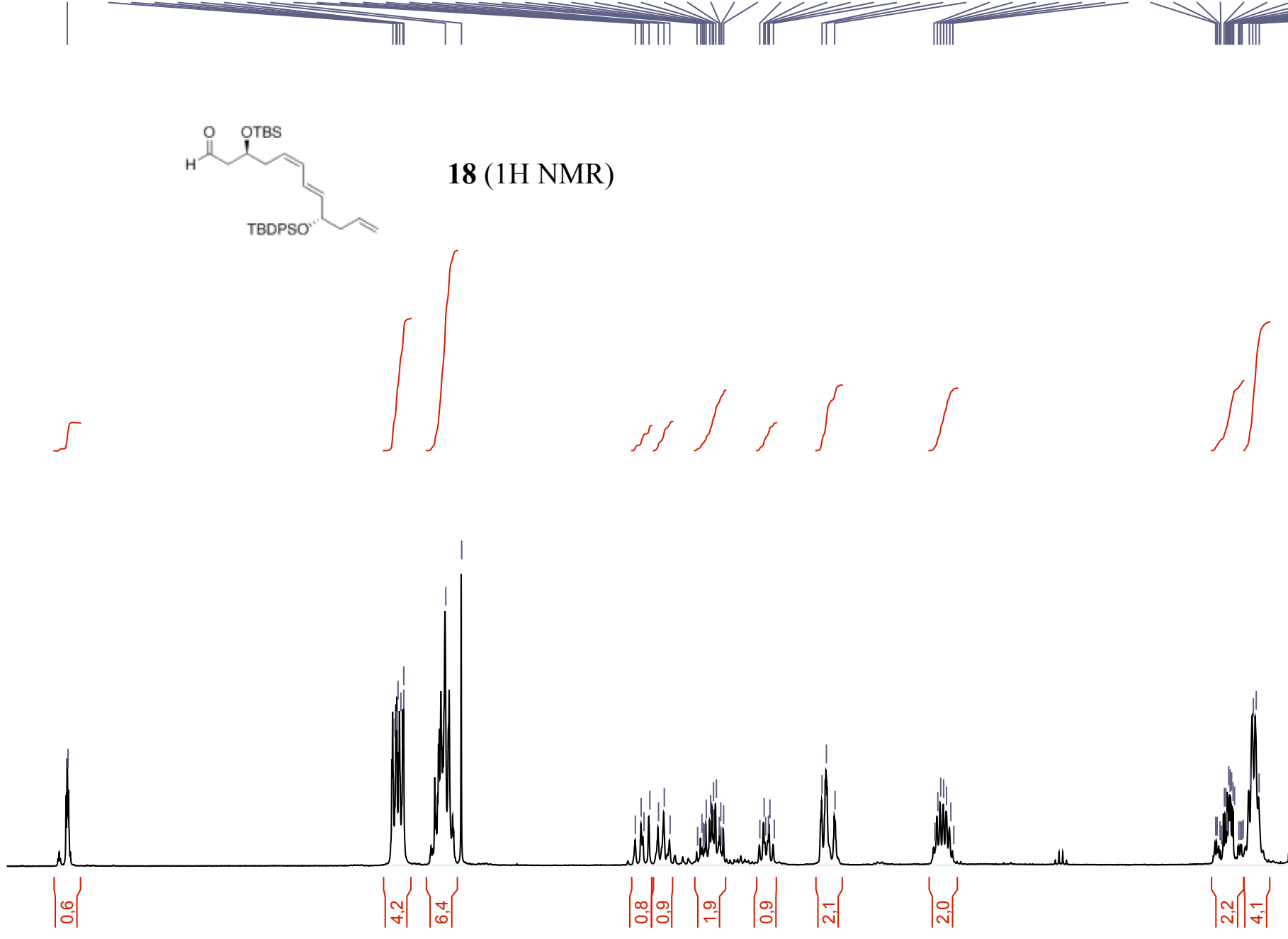
-S34-
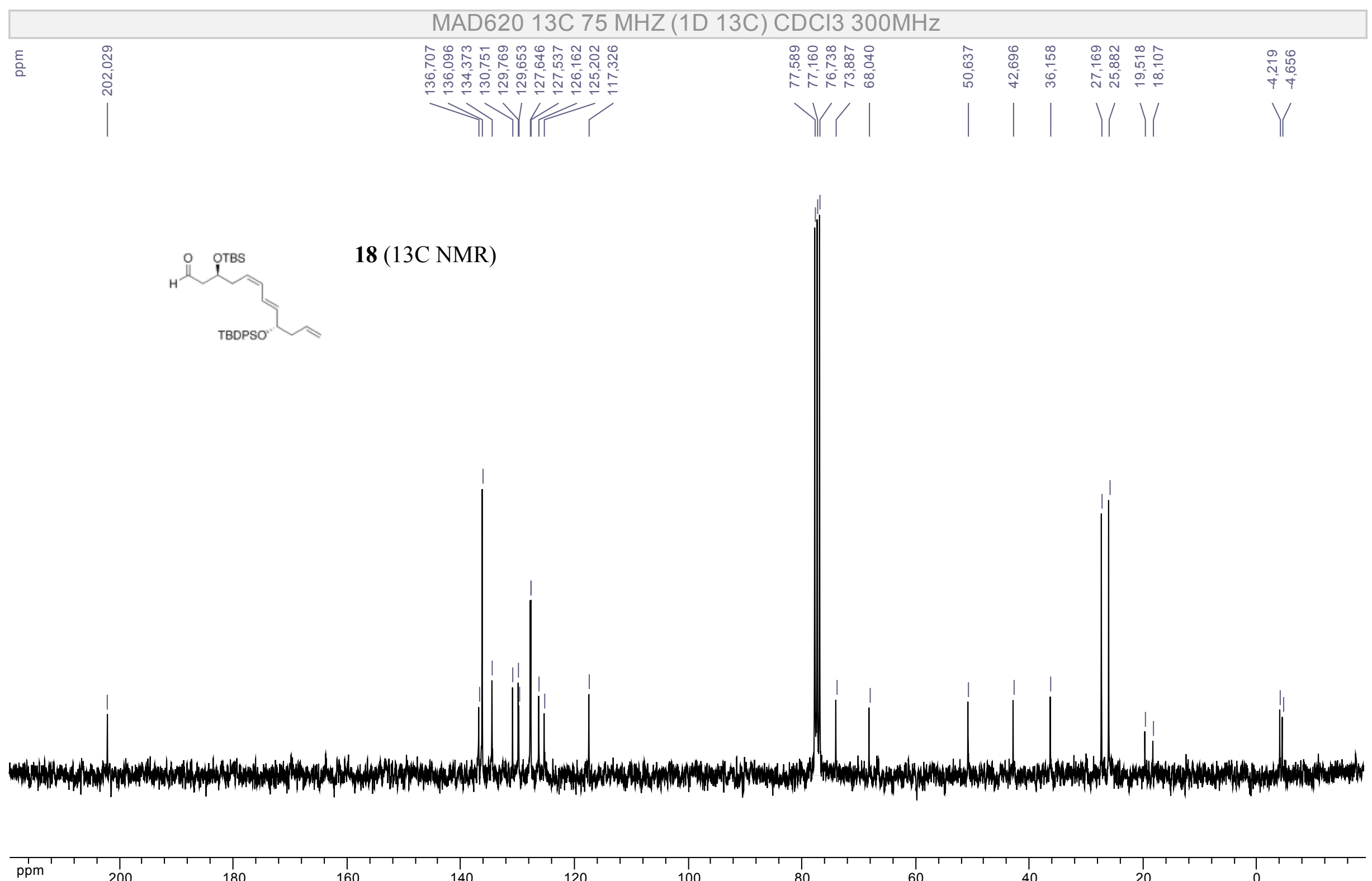

180

160

140

120

100

80

60

40

20

0 
-S35-

MAD628 (1D 1H) C6D6 500MHz

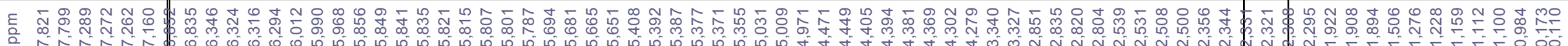
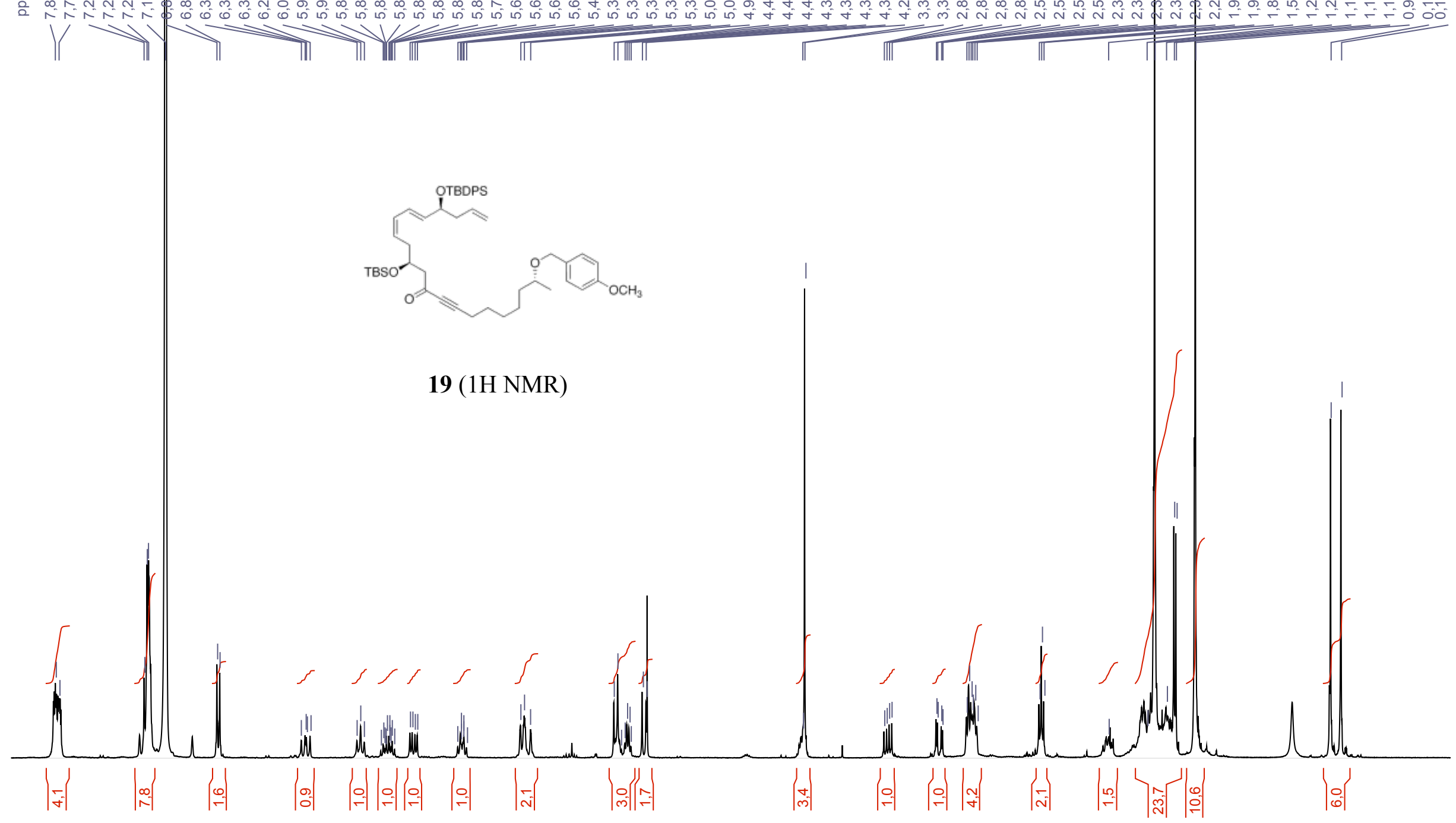


\section{-S36-}

MAD630F2 (1D 1H) CDCl3 300MHz

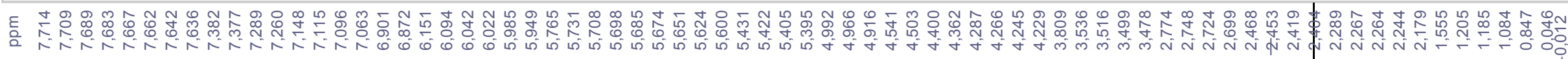

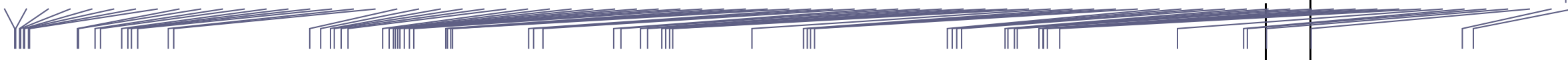

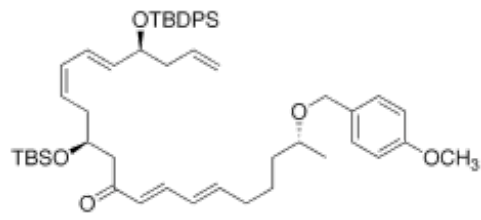

20 (1H NMR)

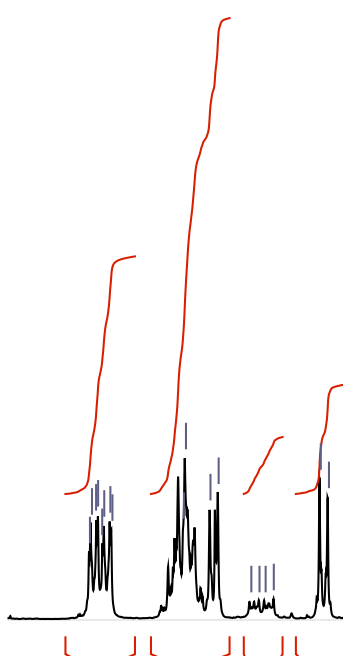

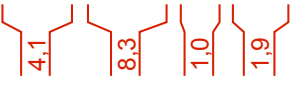

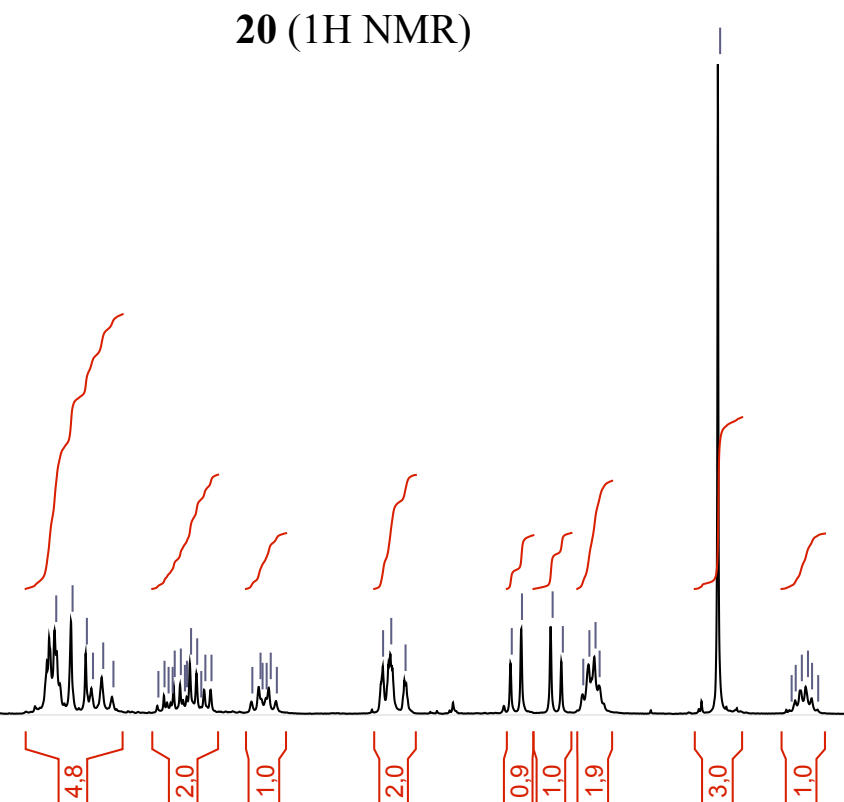
ull $\|_{\|}^{\|}$
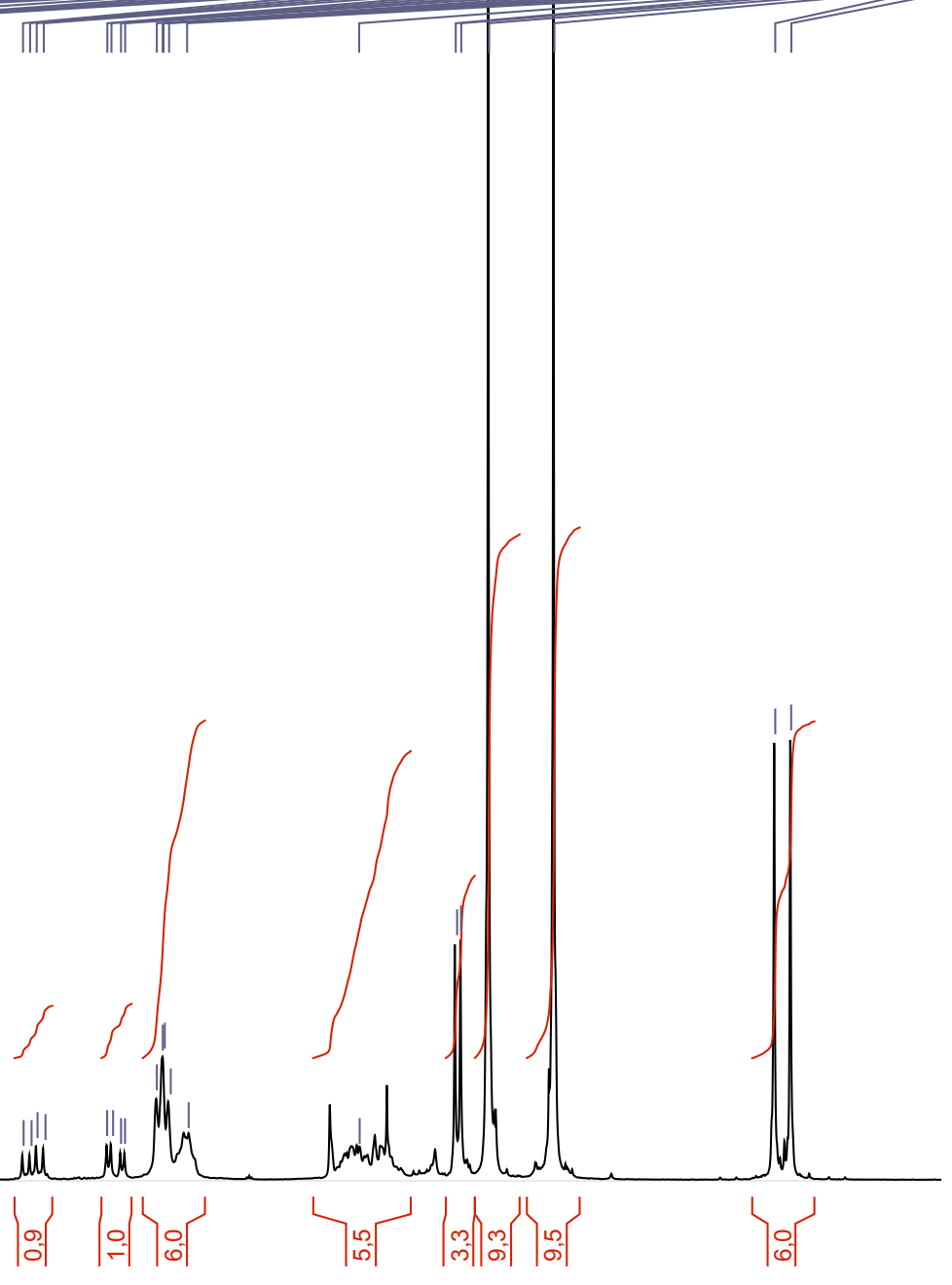

$\mathrm{ppm}_{7,5}$ 
-S37-

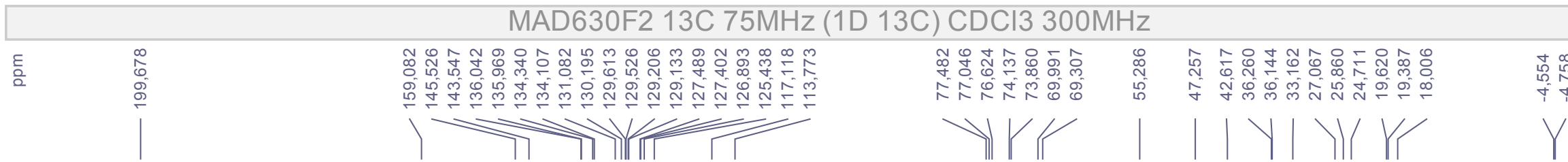

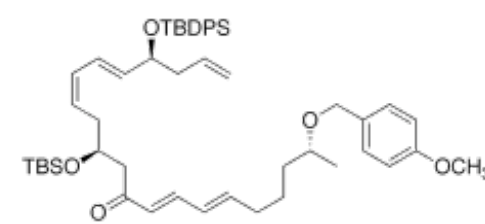

20 (13C NMR)

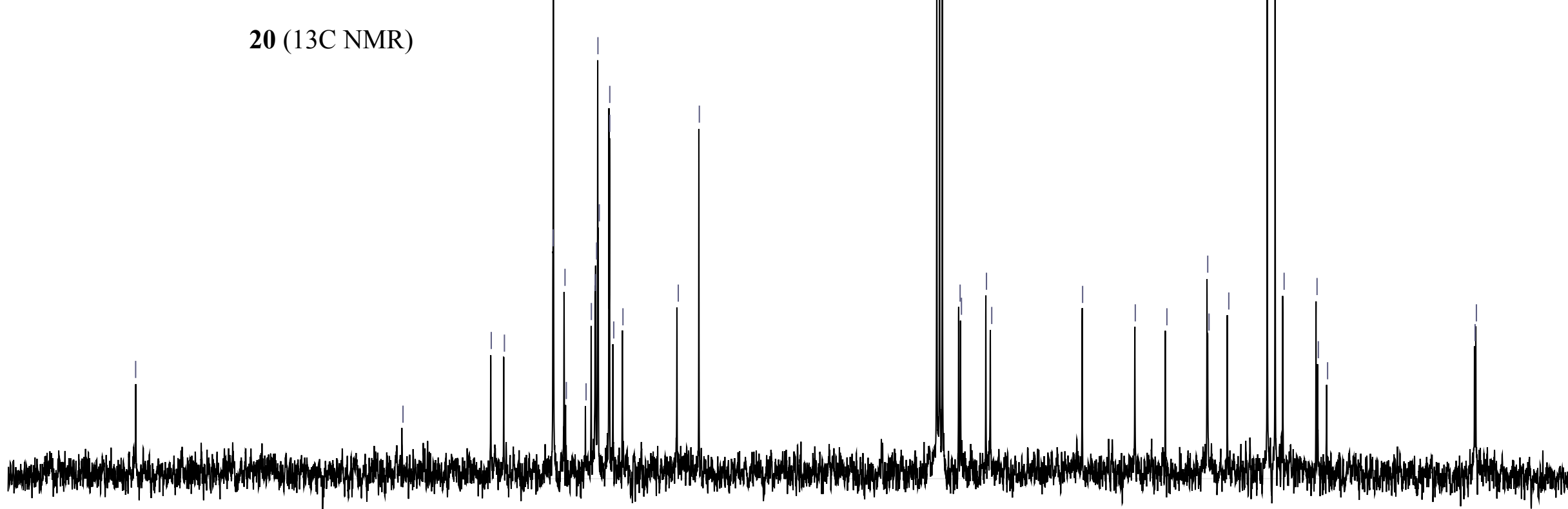

